\title{
Covid-19 Sürecinde Kriz Yönetimi: Türkiye’de Turizm İşletmelerine Yönelik Düzenlemeler
}

\author{
Crisis Management in Covid-19 Process: Regulations For Tourism Businesses in Turkey
}

\section{Yusuf TOKTAŞ}

Yüksek Lisans Öğr., İzmir Kâtip Çelebi Üniversitesi,

SBE, Turizm Isşletmeciliği A.B.D.,

yusuftkts1994@gmail.com

https://orcid.org/0000-0003-3829-0392
Makale Başvuru Tarihi: 28.12.2020

Makale Kabul Tarihi: 17.04.2021

Makale Türü: Araştırma Makalesi
Anahtar

Kelimeler:

Kriz Yönetimi,

Covid-19,

Turizm,

Yönetim,

Keywords:

Crisis Management,

Covid-19,

Tourism,

Management,

\section{ÖZET}

Bu çalışmanın amacı, kavramsal açıdan kriz yönetimini ortaya koymak ve Covid-19 sürecinde Türkiye'deki turizm işletmelerine yönelik düzenlemeleri araştırmaktır. 13 Ocak 2020 tarihinde tanımlanan Covid-19 hastalığı, özellikle turizm sektörünü olumsuz yönde etkilemiştir. Çalışmanın ilk bölümünde krizin kavramsal tanımı yapılarak kriz süreçleri, kriz yönetimi yaklaşımları ve krizin olumlu-olumsuz etkileri sunulmuştur. İkinci bölümde, Covid-19 hastalı̆̆ ile ilgili genel bilgi verilmiştir. Sonrasında, dünyada ve Türkiye'de turizm sektörü üzerindeki etkileri tablolar halinde sunulmuştur. Istatistiki veriler, Birleşmiş Milletler Dünya Turizm Örgütü, T.C Kültür ve Turizm Bakanlı̆̆l ve Türkiye Istatistik Kurumu'nun resmi sayfalarindan elde edilmiştir. Son bölümde, konaklama, ulaştırma ve yiyecek - içecek işletmelerine yönelik düzenlemeler sunulmuştur. Turizm işletmelerine yönelik düzenlemeler, ilgili bakanlıklar ve diğer kurumlar tarafindan yayınlanan genelgeler ve duyurulardan alınarak derlenmiştir. Türkiye ekonomisi için çok önemli bir sektör olan turizmde, kriz yönetimi konusunda Covid-19 pandemisi ile birçok tecrübe edinilmiştir. Bu tecrübelerin gelecekteki krizlerde faydalı olacağı kesindir. Literatür taraması yöntemi kullanılarak, güncel veriler, hükümet yayınları ve genelgeler aracılığıyla hazırlanan bu çalışmanın gelecekteki krizlerin olumsuz etkilerini azaltmada yararlı olması beklenmektedir.

\section{ABSTRACT}

The aim of this study is to demonstrate the conceptual aspects of crisis management and to investigate the regulations for tourism businesses in Covid-19 process in Turkey. Covid-19 disease that defined on January 13, 2020 particularly affected the tourism industry negatively. In the first section of the study, crisis was defined conceptually and crisis processes, crisis management approaches and the positive-negative impacts of crisis were presented. In the second section, general information about Covid-19 was given. Afterwards, its impacts were presented by tables on tourism industry in the world and in Turkey. Statistical data were obtained from the official web sites of the United Nations World Tourism Organization, Republic of Turkey Ministry of Culture and Tourism and Turkey Statistical Institute. In the last section, the regulations for the accommodation, food and beverage and transportation businesses were presented. Regulations for the tourism enterprises were compiled from circulars and announcements issued by the relevant ministries and other institutions. In the tourism industry which is crucial for Turkey's aconomy, a lot of experience were gained with the Covid-19 pandemic. It is obvious that these experiences are going to be benficial for the future crises. This study was prepared using the literature review method, through current data, government publications and circulars is expected to be useful to reduce their negative impacts.
\end{abstract}




\section{GIRISS}

Kriz kavramı hem günlük yaşantımızda hem de birçok bilim dalında kullanılmaktadır. Farklı kullanım alanları nedeniyle birbirinden farklı kriz tanımları yapılmıştır. Bu tanımlamaların temel amacı, krizi anlamak ve krizlerle başa çıkmaktır. Kriz sosyal bilimlerde "bunalım" ve "buhran" kelimeleri ile yakın anlamlarda kullanılırken ekonomi biliminde kriz, finansal olarak kötüleşme, enflasyonist baskı ve arz-talep dengesindeki bozulma durumlarında, politika alanında savaş, siyasi çekişmeler ve sınırların ihlal edilmesi gibi durumlarda kullanılmaktadır (Karakaş, 2018:30). Genel bir ifadeyle kriz; birdenbire ortaya çıkarak veya ortaya çıkmadan önce birtakım sinyaller göndererek örgütlerin işleyişinde aksaklığa neden olan, onları maddi ve manevi zarara uğratan, her ne kadar olumsuz olsa da iyi yönetildiğinde olumlu sonuçlar da sunan olaylar ve durumlardır.

Örgütleri zor duruma sokan ve yaşamsal faaliyetlerini tehdit eden krizler, yerel veya uluslararası sorunlardan kaynaklanabilir. Bazı krizler dünya çapında duyulurken bazıları ise bir işletmenin kendi çevresinde yaşanabilir. Krizler ve küreselleşme arasında tarihsel bir bağlantı söz konusudur. Küreselleşme, ülke sınırlarını kaldırarak toplumları birbirine yakınlaştırır, küresel sermaye yaratır, finansal, politik ve sosyal ilişkileri arttırır (Pira ve Sohodol, 2004:16). Bununla beraber küreselleşme, ekonomik, toplumsal ve sosyal açıdan olumlu sonuçlar doğursa da bazı durumlarda istenmeyen sonuçlara sebep olmaktadır. Sınırların silikleşmesi, bilgi teknolojilerinin gelişmesi, finansal ilişkilerin artması ve sosyal ilişkilerin gelişmesi olumlu olsa da herhangi bir yerde yaşanan bir krizin olumsuz etkileri o yerin sınırlarını kısa sürede aşarak yaşamsal birçok alanı olumsuz etkileyebilmektedir (Küçükaltan vd., 2015). Küreselleşmenin doğasında karşllıklı etkileşim ve denge vardır. Küreselleşme kimi zaman bir krizin doğrudan sebebi olarak görülebileceği gibi kimi zaman da bir krizin hızla yayılmasında etkili olan nedenlerden biri olarak görülebilir.

Küreselleşmenin hem bir sebebi hem de bir sonucu olarak görebileceğimiz turizm sektörünün yerel ve uluslararası krizlerden etkilenme olasılığ ülkelerin kalkınmasında kilit rol oynamakta, küresel sektör özelliği taşımakta ve bu durum sektördeki işletmeleri birçok küresel krizle karşı karşıya getirmektedir (Göral, 2014:397). Turizm, ülkelerin ekonomisine olan olumlu katkısı, doğrudan döviz girdisi sağlaması, önemli ölçüde istihdam yaratması, sosyal ve kültürel gelişmeye olan etkisi, bölgesel kalkınmaya olan faydası ve diğer sektörlere yönelik çarpan etkisi ile günümüzün lokomotif sektörlerinden birisidir. Turizm, bu özelliklerinin yanı sıra hassas ve kırılgan bir sektördür. Temelinde insan hareketliliği olan turizm, dünyada yaşanan doğal, ekonomik, sosyal, siyasi ve ekolojik birçok hadiseden en çabuk şekilde ve büyük oranda olumsuz etkilenen sektörlerden birisidir. Turizmin bu hassas ve kırılgan yapısı, kriz durumlarında gerek kamu gerek özel işletme yöneticilerinin kriz yönetimine göstermesi gereken özeni zorunlu k1lmaktadır.

Dünya Sağlık Örgütü Çin Ülke Ofisi tarafından, 2019'un son günlerinde, Çin'in Wuhan eyaletinde kaynağı bilinmeyen pnömoni (zatürre) vakaları bildirilmiştir. Sonraki iki hafta içerisinde hastalık sebebinin daha önce insanlarda görülmemiş yeni bir koronavirüs (2019-nCov) olduğu, daha sonra hastalığın Covid-19 olarak adlandırıldığı, virüsün SARS CoV (Severe Acute Respiratory Syndrome Coronavirus)'e benzerliği dolayısıyla SARS-CoV-2 olarak adlandırıldığı görülmüsştür. Türkiye'de ilk vaka 11 Mart 2020'de ilan edilmiştir (T.C. Sağlık Bakanlığı Covid-19 Bilgilendirme Platformu, 2020). İlk vakanın duyurulmasıyla birlikte toplumsal yaşam, hükümetlerin ve ilgili örgütlerin aldığı kararlar ile getirdiği düzenlemeler doğrultusunda değişikliğe uğramıştır. Örgütler için yeni bir kriz yönetim süreci başlamıştır. Bu süreçte ekonomik, politik, sosyal, doğal vb. birçok sebepten kaynaklanan krizlere karşı aşina olan turizm işletmelerine yönelik çok sayıda düzenleme hayata geçirilmiştir.

Bu çalışmada ilk olarak kriz, kriz türleri, kriz süreci ve kriz yönetimi konuları ele alınmıştır. Hâlihazırda devam eden salgın sürecinde kriz yönetimine yönelik atılan adımları daha iyi anlayabilmemiz açısından öncelikle krizin tanımının yapılması, kavramların anlaşılması, kriz yönetiminde başarılı olabilmek için krizlerin sınıflandırılması, kriz süreçlerinin ve yaklaşımlarının bilinmesi gerekmektedir. Çalışmanın sonraki kısmında Covid-19 hastalığına, salgının dünyada ve Türkiye'deki güncel durumuna, salgının dünya ve Türkiye turizmine olan etkilerine odaklanılmıştır. Sonrasında ise Türkiye'de Covid-19 sürecinde turizme yönelik kriz yönetimi düzenlemeleri, konaklama, ulaştırma ve yiyecek-içecek işletmeleri kapsamında ele alınmıştır. Küresel çapta olumlu - olumsuz etkiler gösteren ve göstermeye devam eden Covid-19 pandemisine karş1lik alınan tedbirler, uygulamalar, çıkarılan kararnameler ve genelgeler, pandemiyle mücadelenin ve kriz yönetiminin kamu yönetimi bazında yürütüldüğünü göstermektedir. Covid-19 pandemi krizine karşı yürütülen kriz yönetimi süreci incelenirken, hükümet birimleri tarafından turizm işletmelerine yönelik alınan kararlar, politikalar, düzenlemeler ve yürürlüğe konulan genelgelere odaklanılmıştır. 


\section{KAVRAMSAL VE KURAMSAL AÇIDAN KRİZ YÖNETIMI}

Türk Dil Kurumu Sözlüğüne göre kriz kelimesi; "bir organda birdenbire ortaya çıkan fizyolojik bozukluk, akse" ve "bir ülke veya ülkeler arasında, toplumun veya bir kuruluşun yaşamında görülen güç dönem, bunalım, buhran" anlamlarına gelmektedir (Türk Dil Kurumu Sözlükleri, 2020). Kriz sözcüğü etimolojik köken olarak Latince "krinein", Grekçe "krisis" köklerine dayandırılmaktadır ve bu sözcükler de temelde karar verme noktasını işaret eden bir ayrılık anlamını taşımaktadır (Çakmak, 2018:4). Oxford Sözlüğünde kriz; sorunların çözülmesi veya önemli kararların alınması gereken büyük tehlike, zorluk ya da şüphe anı ve bir problemin, bir rahatsızlı̆̆ın ya da bir durumun en kötü noktasında olduğu zaman olarak tanımlanmaktadır (Oxford Learner's Dictionaries, 2020). Kriz ve kriz yönetimi konularında yapılan çalışmalarda kriz kavramına dair farklı tanımlamalar mevcuttur. Bu tanımlardan bir tanesine göre kriz (Can, 1997:312; Topuz, 2009:3); "sosyal bilimler alanında çoğu kez "buhran" ve "bunalım" kelimeleri ile eş anlaml olarak kullanılmaktadır. Ekonomik kriz, mali kriz, siyasi kriz, hükümet krizi, ahlak krizi vb. kavramlara sadece günlük dilde değil, bilimsel terminolojide de çok sik rastlamaktayız". Başka bir tanıma göre kriz; "bir örgütün üst düzey hedeflerini ve işleyiş düzenini tehdit eden, bazen de örgütün yaşamını tehlikeye atan ve ivedi tepki gösterilmesini gerektiren, örgütün kriz önleme mekanizmalarınin yetersiz kalmasına neden olan, örgütte gerilim yaratan bir durumdur" (Aktan, 2004).

Kriz Yönetimi Enstitüsü (Institute For Crisis Management)'nün kriz tanımı; “Bir örgütün itibarını, işini ve finansal gücünü etkileyebilecek olumsuz paydaş tepkilerini tetikleyen herhangi bir sorun, problem veya aksaklık" (Institute For Crisis Management, 2020), şeklindedir. Ayrıca Çincedeki "Wei-Ji" sembollerinin "firsat içeren tehlike" anlamına geldiğine dair yaygın bir yanlış anlaşılma söz konusudur. Esasen "Wei" sembolü "tehlike" anlamına gelse de "Ji" sembolü firsat değil, "değişim ve dönüşüm noktası" anlamına gelmektedir (Milasinovic ve Kesetovic, 2008:168). Buradan yola çıkarak krizin her ne kadar ilk duyulduğunda olumsuz bir anlamı ve tınısı olsa da aslında tamamen olumsuz bir kavram olmadığı ve içerisinde değişim için firsatlar da barındırdığı sonucuna ulaşılabilir. Krizler bir değişim ve dönüşüm noktası içerebilir ancak her kriz bir firsat anlamına gelmemektedir. Krizler doğaları gereği olumlu ve olumsuz özelliklere sahip olmakla beraber, bir krizin fırsata çevrilmesinde örgütlerin kriz yönetimindeki becerileri belirleyici olmaktadır. Yapılan tanımlamalar 1şığında krizlerin birtakım karakteristik özellikleri olduğunu söyleyebiliriz. Boin ve Lagadec (2000:186) küresel krizlerin ortak özelliklerini aşağıdaki gibi sıralamıştır;

- Krizler, nüfusun büyük bir kısmını kapsayan geniş çaplı etkilere sahiptir.

- Krizlerin yüksek ekonomik maliyeti, klasik sigorta yeterliliklerine baskın çıkar.

- Kriz zamanlarında benzeri görülmemiş, kapsamlı ve bileşik problemler hayati kaynakları etkiler.

- Krizler çoklu yapıları sebebiyle kartopu etkisi oluşturur.

- Eski, uygulanması mümkün olmayan ve verimsiz prosedürler, acil durum sistemlerinin yanlış zamanlamalarda tepki vermesine sebep olabilir.

- Aşırı belirsizlik, acil durum dönemleri dışında da devam edebilir.

- Kriz dönemlerinde tehditler zamanla değişikliğe uğrayabilir ve dönüşebilir.

- Kriz anında çok sayıda aktör ve örgüt bir araya gelip yakınlaşabilir.

- Sorumlu örgütlerle halk, medya ve mağdurlar (zaman ve mekân bakımından çok uzakta olan topluluklarla bile) arasında ciddi iletişim sorunları yaşanabilir.

- Her türde dikkate değer firsatlar ortaya çıkabilir.

Kriz için yapılan tanımlamalara ve krizin özelliklerine baktığımızda krizlerin örgütlerde stres yarattığını, zaman baskısından dolayı karar mekanizmalarında psikolojik baskı oluşturduğunu, belirsizlik ve korku ortamı yarattıkları için özellikle yönetici olmayan kişilerde kaygı ve endişe yarattığını, örgütlerde çok kısa bir süre içinde kargaşaya sebep olduklarını, etkilerinin uzun süreli olabileceğini söyleyebiliriz.

\subsection{Krizin Nedenleri}

Krizler doğaları gereği birçok farklı sebepten kaynaklanırlar. Krizlerin ortaya çıkma sebeplerindeki bu farklılık, kriz yönetiminde kolaylık ve işlevsellik sağlaması açısından, krizleri türlerine göre sınıflandırılmasını gerekli 
kılmaktadır. Krizler sınıflandırılırken ortaya çıkış sebeplerine ve kaynaklarına dikkat edilmektedir. Krizler bazen örgütlerin doğrudan müdahale edemediği, örgütün uzak çevresinde ve örgütün dışından kaynaklanan etkenlerden meydana gelmektedir. Bununla beraber bazı krizler de doğrudan örgütlerin içinden, örgütün yakın müdahale alanında ve içsel sebeplerden dolayı ortaya çıkmaktadır. Bundan dolayı krizin nedenleri dış faktörler ve iç faktörler olarak ikiye ayrılmaktadır.

\subsubsection{Krize Sebep Olan Dış Faktörler}

Ülkeler, küreselleşmenin ve çağ atlatan teknolojilerin etkisiyle iletişim ve bilgi akışı açısından birbirlerine daha yakın hale gelmiş̧lerdir. İlişkilerdeki artış pek çok konuda olumlu sonuçlar sağlasa da beraberinde birçok kriz potansiyeli getirmektedir. Ekonomik, siyasi, kültürel, toplumsal, teknolojik, sosyal ve biyolojik alanlarda yaşanan krizler kısa zamanda hızlıca yayılabilmektedirler. Demir ve Yılmaz'ın (2010:69-88) ifade ettiği üzere; "Her alanda çok hızlı bir değişimin yaşandı̆̆ı günümüzde, örgütlerin ayakta kalabilmesi ve gelişebilmesi için, değişimleri ve bunlardan meydana gelecek sonuçları önceden tahmin etmeleri, ortaya çıkacak firsat ve tehditleri en iyi şekilde değerlendirmeleri gerekmektedir".

\subsubsection{Ekonomik Faktörler}

İşletme yönetimi söz konusu olduğunda kriz kelimesi öncelikle işlemenin finansal tablolarındaki sıkıntıyı, yani ekonomik krizi akla getirmektedir. Ekonomik krizler; "Herhangi bir mal, hizmet, üretim faktörü veya döviz piyasasındaki fiyat velveya miktarlarda, kabul edilebilir bir değişme sınırının ötesinde gerçekleşen şiddetli dalgalanmalar" (Kibritçioğlu, 2001:1) şeklinde tanımlanabilir. Yöneticilerin söz konusu şiddetli dalgalanmalara karşı hazırlıklı olmaları, ekonomik kriz fırtınası sona erdiğinde işletmeyi mümkün olan en az zararla varacağı yere götürmelerini sağlayacaktır. Günümüzde devletler ve işletmeler, küresel bir ekonomik sistemin birer parçasıdırlar. Kapitalizmin ve Türkiye'de de 1980 'li yıllardan itibaren kabul edilen liberal ekonominin bir gerekliliği olarak örgütler dış gelişmelere, dış dünyaya ve etkilerine açıktırlar. Örneğin 2008 yılında yaşanan küresel ekonomik kriz başta ülke ekonomileri olmak üzere birçok işletmeyi olumsuz etkilemiştir.

\subsubsection{Hukuki ve Siyasi Faktörler}

Siyasal krizler, bir ülkede yönetimin aşırı otoriterleşmesi veya ülkeler arasında yaşanan siyasi sorunlar, sinır anlaşmazlıkları, savaşlar ve çatışmalar, ülkelerin birbirlerinin iç işlerine müdahalesi, ekonomik ve siyasi ambargolar gibi sebeplerden kaynaklanabilmektedir. Bu krizler ülke içinde faaliyet gösteren işletmeleri olumsuz yönden etkilemektedir. Rusya'ya ait bir savaş uçağının sınır ihlali yapması sebebiyle Türk Hava Kuvvetleri tarafından 2015'in Kasım ayında düşürülmesinin ardından, Türkiye ve Rusya arasında siyasi gerginlik yaşanmış, Rus hükümetinin Rus turistlerin Türkiye'de tatil yapmalarını engelleme girişimleri sonucunda Türkiye'yi ziyaret eden Rus turist sayısında bir önceki sezona göre düşüş olmuştur. İşletmelerin hükümet politikalarını ve hukuki değişiklikleri yakından takip etmeleri gerekmektedir. Devletlerin işletmeler üzerinde uyulması gereken hukuki düzenlemeler ve yasalar sebebiyle bir otoritesi söz konusudur. Dolayısıyla güncel hukuki düzenlemeleri takip eden ve bunlara uyum sağlayan işletmeler yasal yaptırımlardan ve cezalardan kaçınabileceklerdir.

\subsubsection{Doğal Faktörler}

İşletmelerde krize sebep olan doğal faktörlerin kontrolü mümkün değildir ve bu faktörler işletmenin doğal çevresiyle ilgilidir. Sel, deprem, yangın, heyelan ve buna benzer doğal afetler yalnızca işletmeyi değil, bölgede yaşayan diğer insanları da etkilemektedir. Krize sebep olan diğer faktörler ile doğal faktörler arasındaki temel fark; doğal afetler sonucunda meydana gelen krizlerin etkisinin daha derin ve uzun vadeli olmasıdır. Bununla beraber doğal nedenlerle yaşan krizlere karşı uyarı sistemleri son dakikada, yani afetler yaşanırken çalışır veya hiç çalışmaz. Dolayısıyla işletmelerin krizi önlemek ve sarsıcı etkilerini azaltmak için yeterli vakti yoktur. Bu sebeple ilk yardım ve acil durum ekipleri kurulmalı ve olası bir afet durumunda uygulanacak iş planı yapılmalıdır (Bozkulak, 2019:53). İşletmelerin kuruldukları yerlerde meydana gelen doğal felaketler örgütleri doğrudan ve fiziki olarak etkileyebileceği gibi, uzak bir noktada meydana gelen doğal felaketler de işletmeleri ve örgütleri birçok açıdan olumsuz etkileyebilir ve krize sebep olabilir. Örneğin 2010 yılının Nisan ayında İzlanda'da gerçekleşen yanardağ patlamaları sonucu ortaya çıkan kül bulutları sebebiyle Avrupa'da hava yolu 
trafiği sekteye uğramış, ABD-Avrupa uçuşlarının \%50'si iptal edilmiş, yaklaşık 17 bin sefer iptal olmuş, o dönem için yapılan rezervasyonlar ertelenmiş veya büyük oranda iptal edilmiştir (Amerika'nın Sesi / Voice Of America, 2020).

\subsubsection{Teknolojik Faktörler}

Teknolojinin temelinde teknik vardır. İşletmelerin sunduğu mal ve hizmetlerin hem üretiminde hem de sunumunda kullandıkları teknikler, teknolojinin özellikle son 20 yılda gösterdiği büyük gelişme ve ilerleme ile birlikte gelişme kaydetmiştir. Toplum ve endüstri arasındaki birbirini besleyen ve ileriye doğru iten ilişkinin bir sonucu olarak işletmeler teknolojiyi yaygın ve verimli bir şekilde kullanır hale gelmişlerdir. Bununla beraber teknolojinin de birçok krize doğrudan veya dolaylı olarak yol açtığı görülmektedir. Çiftçi’nin (2015:52) de ifade ettiği üzere;

"Günümüzde teknolojik değişikliklere uyum sağlamak, gelişmek zorunda olan işletmeler için bir ihtiyaçtır. Işsletmenin kullandığ teknik ve yöntemlerde hizlı bir değişme söz konusuysa, bunun işletmenin temel amaçlarını etkileyeceği açıktır. Krizin ortaya çıkmasında teknolojik değişikliklerin hızı, değişikliğe uyum süreci ve teknolojiye bağımlılı̆̆ı oranı önemli ölçüde etkili olacaktır. Özellikle, gelişen bir teknoloji, işletmenin arz ettiği mal ve hizmetin yerine ikame edilebilecek yeni mamuller ve faaliyet alanları çıkmışsa örgüt için kriz kaçınılmaz olabilir."

Çağdaş işletmeler, Endüstri 4.0 uygulamalarını kullanmaya başlamıştır şimdiden Endüstri 5.0'ın planlamaları yapılıp temelleri atılmaktadır. Örgütlerin gelişen teknolojiye ayak uydurması kaçınılmazdır çünkü inovasyona (yenilik) kapalı örgütler gelişmeye ve yeniliğe açık örgütlerin gerisinde kalmaktadırlar. Her ne kadar teknoloji sürekli gelişip değişse de insanların zaruri ihtiyaçları aynı kalmaktadır. Bu ihtiyaçların temelinde bulunan güvenlik ihtiyacı, gelişen teknoloji ile birlikte açığa çıkan siber suçlar ve veri hırsızlığı neticesinde daha da önem kazanmıştır. Bu nedenle işletmelerin hem teknolojiye uyum sağlaması hem de bu güvenlik ihtiyacını göz ard1 etmemeleri gerekmektedir.

\subsubsection{Sosyal ve Kültürel Faktörler}

Bir arada yaşayan insanların ortak inançlarına, değerlerine, hareket, davranış ve tutumlarına kültür denir. Bireyler tarafından paylaşılan kültür; toplumların yıllar boyunca üretip geliştirdiği, o topluma has yaşam biçimidir. İşletmelerin faaliyetlerini toplumun sahip olduğu inançlara ve değer yargılarına göre yürütebilme kabiliyetine sahip olmaları gerekmektedir. İşletmeleri krize sevk eden sosyo-kültürel etkenlerden birkaçı; değişen değer yargıları, azalan müşteri ilgisi, sosyal karışıklıklar ve huzursuzluklardır. Bununla beraber göçler, kadınların toplum içindeki yeri, değişen yaşam tarzları gibi faktörler de işletmelerin amaçlarını etkilemektedir. İşletme yöneticilerinin üzerine düşen, toplumdaki söz konusu değişimlere uygun stratejileri hayata geçirmektir. Sosyo-kültürel faktörleri dikkate almayıp uygun stratejiler geliştirmeyen işletmelerin krizle karşılaşması kaçınılmazdır (Karaca, 2003:7). Örgütlerin sosyo-kültürel faktörlere uyum sağlaması olası krizleri önlemede etkili bir faktördür. İşletmenin kurulduğu bölgede yaşan insanların hayata bakışı, değer yargıları ve tutumları, dünya görüşleri, kutsalları, eğitim seviyeleri, kültürel gelişmişlik düzeyleri gibi faktörlere uyum sağlayamayan örgütlerin krizle karşılaşmaları kaçınılmazdır.

\subsubsection{Biyolojik Faktörler}

Biyolojik krizler, başta insanlar olmak üzere hayvanlarda ve bitkilerde biyolojik hasara ve rahatsıliklara yol açan durumlardır. Biyolojik savaş, biyolojik terör, biyoterörizm olarak da bilinen biyolojik krizler, çoğunlukla kimyasal reaksiyonlar ile salgın hastalıklar şeklinde karşımıza çıkmışlardır. 1986'nın Nisan ayında meydana gelen Çernobil faciasından 2015'te ortaya çıkıp hala etkisini sürdürmekte olan MERS salgınına ve hâlihazırda hayatımızın bir parçası olan Covid-19 salgınına kadar birçok hadise biyolojik faktörlere örnek verilebilir. Biyolojik krizler belli bir bölgede ortaya çıkarlar ancak etkileri küresel çapta olabilir. Dünyada sınırların büyük oranda kalkması, seyahat sıklığının zirveye ulaşması ve insan hareketliliğinin artması gibi nedenlerden dolayı biyolojik rahatsızlıklar ve hastalıklar dünyanın bir ucundan diğer ucuna daha çabuk şekilde yayılabilmektedir. Dolayısıyla bu yayılma kısa sürede etkisini birçok yerde gösterebilmektedir. 


\subsubsection{Krize Sebep Olan İç Faktörler}

Örgütler, birçok unsurun bir araya gelmesiyle oluşan sistemlerdir. Örgütleri oluşturan başlıca unsurlar; yöneticiler, çalışanlar, tedarikçiler, sermaye sahipleri, iş ortakları ve rakiplerdir. Bununla beraber, örgütsel yapı, örgütün kültürü, değerleri, vizyonu, misyonu ve iç dinamikleri, örgütün oluşmasında ve varlığını devam ettirmesinde etkili olan soyut unsurlardır. Örgütler, saydığımız soyut ve somut unsurların bir araya geldiği sistemlerdir ve bu unsurlar aynı zamanda krizlere sebep olan iç faktörler olarak da görülebilir. Kamu ve işletme yönetiminde yaşanan krizlerin birçoğu diş faktörlerden kaynaklanıyor gibi görünse de aslında krizlerin çoğu iç faktörlerden kaynaklanmaktadır. Dış faktörlerden kaynaklanan krizlerin örgüte ulaşması ve etkilemesi iç faktörlerden kaynaklanan krizlere göre daha fazla zaman alır. Bununla beraber iç kaynaklı krizler örgütün yakın müdahale alanında yaşandığı için yönetimin krizlere müdahalesi doğrudan ve daha etkili olabilmektedir. Dolayısıyla, içsel faktörleri başarıyla yöneten örgütler, iç faktörlerden kaynaklanan krizlere yakalanma olasılığını azaltacak ve dış faktörlerden kaynaklanan krizleri de başarıyla yöneteceklerdir.

\subsubsection{Yönetsel Faktörler}

Yönetim konusunu insanlık tarihi ile birlikte ele almak mümkündür. En az iki kişiden oluşan gruplardan kalabalık kabilelere ve topluluklara, topluluklardan sayıları milyonları bulan toplumlara kadar her bir grupta bir lider ve yönetici olmuştur. Yönetici, aynı kültürü, motivasyonu ve hedefi paylaşıtığı topluluğu idare eden kişidir. Bu kişi bazen liderliğin doğası gereği kendiliğinden bazen de yönetilenlerin iradesiyle yönetici olarak tanınır. Modern ve modern sonrası yönetim anlayışında örgütlerde alt, orta ve üst kademe yöneticilerin olduğunu görmekteyiz. Bu kademeler arasındaki iletişimsizlik, yöneticilerin yetersiz ve tecrübesiz olması, çalışanların gerektiğinde ödüllendirilmemesi, örgüt yapısının örgüt stratejilerine uygun olmaması gibi nedenler yönetsel krizlere yol açmaktadır. Genç'e (2004:344) göre;

"Örgütler her ne kadar sistem olmanın bir gereği olarak ele alınıp, örgüt yönetimi bir "ekip işi”" olarak kabul edilse de başarıda yöneticinin rolü ne kadar önemli ise başarlsız bir yönetimin sonucu ortaya çılkan kriz durumunda da yetersiz ve yeteneksiz yöneticinin rolü o kadar önemlidir. Yönetici bugünün problemlerini dünün çareleriyle çözmeye kalkıyorsa veya bugünkü dünyayl, dünün kafastyla algilama ve yorumlama yoluna gidiyorsa, örgütte bizzat yöneticinin kendisi kriz kaynă̆ıdır."

\subsubsection{2. Örgütün Yaşam Döngüsü}

Örgütleri birer canlı organizma olarak görebiliriz. Örgütler de doğar, büyür, çoğalır, bölünür, genişler, yaşlanır ve hayatta kalması için gerekli olan koşullar ortadan kalktığında yok olurlar. Köroğlu (2004:24)'na göre; ' Bir örgütün hayat safhasl; doğuş, gelişme, olgunlaşma, gerileme ve çöküş olmak üzere beş aşamadan oluşmaktadır ve bu yaşam ĕgrisinin gerektirdiği faaliyetleri yerine getiremeyen örgütler olası bir tehditle karşılaşabilirler". Örgütlerin yaşam döngülerinden kaynaklanan krizler ile ilgili başka bir görüş ise şu şekildedir (Uzun, 2001:40; Topuz, 2009:10);

“Greiner tarafindan 1972'de ileri sürülen görüşe göre, işletmeler yaşam süreleri boyunca, her gelişme evresi sonunda çeşitli kriz durumlarıyla karşılaşmaktadırlar. Bu görüşe göre, işletmenin ilk kuruluş aşamasinda liderlik, gelişme aşamasında yetki devri krizleri, olgunlaşma aşamasında bürokrasi krizleri, gerileme aşamasında ise yeniden canlanma ihtiyacindan doğan krizler yaşanmaktadır. İşletmeler bu aşamada detayl analizler yaparak yeniden canlanmayı gerçekleştirmek zorunda kalmaktadır. Bu noktada işletme, küçülme, sürekli olgunluk ve çökü̧s olmak üzere üç seçenekle karşı karşıya kalmaktadır."

\subsubsection{3. Örgütün Büyüklüğü ve Karmaşılığı}

Örgütlerin büyüklüğü arttıkça örgütsel yapılarındaki karmaşıklık da aynı ölçüde artmaktadır. Büyük ve karmaşık örgütlerin krizlere yakalanma eşiği daha düşük, krizlerden etkilenme oranları ise daha yüksektir. Yılmaz'a (2004) göre; iletmeler büyüdükçe, dikey, yatay ve coğrafi açıdan yayılma eğilimi göstermektedirler. Aynı zamanda büyümeyle birlikte faaliyetleri genişlemekte ve işletme çevresi karmaşık bir hale gelmektedir. Bu durum, iletişim, koordinasyon ve kontrol sorunlarını ortaya çıkarmaktadır. Diğer yandan, işletmelerin büyümesi 
ve karmaşıklık derecelerinin artması her zaman krizlere neden olmamaktadır ancak büyük ölçekli işletmelerin karşı karşıya kaldıkları kriz durumlarının sonuçları küçük ölçekli işletmelere göre daha yıkıcı olabilmektedir (Y1lmaz, 2004:24-25).

\subsection{Kriz Yönetimi}

Kriz yönetimi kavramının ilk kez kullanıldığı alan politikadır. Dönemin ABD başkanı J. F. Kennedy’nin kriz yönetimini 1962 'de ABD ve SSCB arasında yaşanan Küba Krizi esnasında, ciddi ve olağandışı bir durumu ele almak, şeklinde tanımlamıştır (Glaesser, 2005:10). Demirtaş (2000:363)'a göre kriz yönetimi; "Olası kriz durumuna karşılık, kriz sinyallerinin alınarak değerlendirilmesi ve örgütün kriz durumunu en az kayıpla atlatabilmesi için gerekli önlemlerin alınması ve uygulanması" sürecidir. Kriz yönetimi için yapılan başka bir tanımlama ise, "Kriz yönetimi, krizlerin sebep olacağl zararları minimum seviyeye indirme amacıla plan oluşturma, olası krizlere karşı sinyallerin önceden alınması ve krizin mümkün olan en az kayıpla geçmesi için ön görülerin belirlenmesi ve uygulanma sürecidir" (Akgemci, 2008:448; Aşık, 2016:17), şeklindedir.

Topuz (2009) kriz yönetimini; "Kriz olarak nitelendirilen durumu ortadan kaldırmak için planll, sistematik ve rasyonel bir biçimde uygulanan faaliyetler topluluğudur. Sistematik olarak adım adım verilecek kararları, bu kararları uygulayacak ekibi oluşturmayl, uygulama sonuçlarını hızla alarak, yeni kararlar vermeyi kapsar", şeklinde tanımlamaktadır (Topuz, 2009:25). Son olarak Mitroff ve arkadaşları oluşturdukları Kriz Yönetimi Modeli'nde kriz yönetimini ve sürecini birbiriyle bağlantılı ve geçişli dört aşamayla göstermiş, kriz yönetimini krizlerin örgütlere olası zararlarını azaltmayı ve kontrol altına almayı sağlayan bir araç olarak ifade etmişlerdir (Mitroff vd., 1987:284). Kriz yönetiminin tanımlarından yola çıkarak kriz yönetimi ile ilgili şu yargıya ulaşabiliriz; kriz yönetimi, örgütler için sürekli uygulanması gereken bir yönetim şekli değildir ancak yöneticiler ve çalışanlar daima kriz durumlarına hazırlıklı ve teyakkuzda olmalıdırlar çünkü kriz yönetiminin temel amacı örgütleri krize düşmekten korumaktır. Booth’a (1990:381) göre kriz yönetiminin amaçları aşağıdaki gibidir;

- Yöneticilere, onları etkileyebilecek krizlerin çeşitleri ve aşamaları hakkında bilgi vermek.

- Yöneticilere, performans izleme vasıtasıyla krizleri tanıma yeteneği kazandırmak.

- Krizden kaçınma planlarını geliştirme konusunda yeni teknikler kazandırmak.

- Yöneticilere, krizi mümkün olan en iyi şekilde yönetme konusunda yetenekler kazandırmak.

Buraya kadar yaptığımız tanımlar ve belirttiğimiz amaçlar neticesinde kriz yönetiminin çıktılarını aşağıdaki gibi siralayabiliriz;

- Kriz yönetimi sayesinde örgütler muhtemel krizlere karşı sürekli hazır bir vaziyette olacaktır.

- Kriz yönetimi çok aşamalı ve karmaşık bir süreci ifade eder. Her aşamanın ayrı ayrı planlanması gerekir.

- Kriz yönetiminin konusu, örgütlerin yaşamlarına kast eden ve faaliyetlerini sekteye uğratan hayati durumlardır. Kriz yönetimi, olağan zamanlarda olağan dışı durumları düşünmektir.

- İyi çalışılmış bir kriz yönetim planı sayesinde örgütler krizleri kısa zamanda kontrol ederek kayıp ve hasarları azaltabilirler.

- Her örgütün DNA'sı kendine özgüdür. Bu nedenle olağan dışı durumlara verdikleri tepkiler benzese de söz konusu kriz yönetimi olduğunda uygulamaların birbirinden farklı olduğu görülmektedir (Akgemci, 2008:448; Topuz, 2009:26).

Kriz yönetiminin özellikleri ile ilgili daha geniş kapsamlı bir sıralama da aşağıdaki gibi yapılmıştır (Şahbaz ve Tuna, 1998:156; Şahin, 2005:59);

- Kriz yönetimi, örgütün yönetim kademesiyle ilgilidir ve stratejik yönetim ile iç içedir. Stratejik yönetimin bir gereği olarak dış çevre analiz edilir ve uzun vadeli planlamalar yapılır. Yönetimin temel fonksiyonları olan planlama, örgütleme, yöneltme ve kontrol, stratejik yönetimin olmazsa olmazlarıdır.

- Kriz yönetimindeki bir diğer önemli husus karar verme sürecidir. Yöneticiler daima bir karar verme durumundadırlar ve aldıkları kararlar ile örgütü yönlendirerek başarılı veya başarısız olmasına neden olurlar.

- Yöneticilerin aldıkları kararların niteliği ve işlevselliği çok önemlidir. Olası bir kriz anında önceden alınmış kararların hayata geçirilebilir ve uygulanabilir olması gerekir. Kriz patlak verdiğinde çalışmayan 
bir kriz yönetim planı örgütü kaosa sürükleyecektir. Öte yandan doğru ve isabetli kararların örgüte olumlu etki etmesi de mümkündür.

- Kriz yönetimi tek aşamalı bir süreç değildir. Kriz yönetiminde temel amaç, muhtemel krizlere karş1 hazırlıklı olmak ve onları bu şekilde karşılamaktır. Kriz yönetim planları olası bir krizde işlerin nasıl ve kim tarafından yapılacağına dair bilgileri içerir.

- Kriz yönetiminin önemli kazanımlarından bir tanesi de iç paydaşlar arasındaki dayanışmayı öne çıkarmasıdır. Etkili bir kriz yönetimi ile örgüt içindeki çatışmalar ve gerginlikler son bulur. Aynı sektörde hizmet veren işletmeler kriz durumlarında birbirlerine destek olarak krizi birlikte atlatmaya çalışırlar. Dolayısıyla kriz yönetim planlarında paydaşlara da yer verilmesi gerekmektedir.

- İster kamu işletmesi ister özel işletme olsun, kâr amacı güden veya gütmeyen hemen hemen her örgütün belli başı harcamaları ve giderleri vardır. Örgütlerin sıradan faaliyetlerinin dışında olan kriz yönetim planları örgütlere ek maliyet yükler. Kriz henüz ortada yokken ödenmesi gereken mali bedelden kaçınan ve önemsemeyen işletmeler, kriz kendisini gösterdiğinde hazırlıksız oldukları için en ağır bedeli ödemek durumunda kalacaklardır.

\subsubsection{Kriz Yönetim Süreci}

Kriz yönetim süreci; örgütü kriz durumuna sokma ihtimali olan olayların ve durumların belirtilerini sezme, örgütün krize yakalanmasını engelleyecek tedbirleri alma, örgüt krize yakalanırsa krizin etkilerini en aza indirme, kriz sona erdiğinde yaşananlardan gerekli dersleri çıkarma ve kontrol gibi faaliyetleri içeren olağandışı bir süreçtir (Göral, 2014:423). Krizden kurtulmak veya krizin olumsuz etkilerini azaltmak için hayata geçirilmesi gereken yönetim politikaları yetkin kişiler tarafından gerçekleştirilmelidir ve kriz yönetim süreci iyi planlanmalıdır (Küçükaltan vd., 2015:44). Bu doğrultuda kriz yönetim sürecinin en iyi biçimde planlanıp yönetilmesi için bu süreci kriz öncesi, kriz dönemi ve kriz sonrası olarak 3'e ayırabiliriz.

\subsubsection{Kriz Öncesi Dönem}

Kriz öncesi dönem, bir örgütün olası krizleri önceden sezmesi, takip etmesi ve bu krizleri önlemeye yönelik tedbirleri almasını kapsayan süreçtir (Guliyev ve Tozkoparan, 2020:53). Çiftçi (2015)'nin “Krize Hazırlık Dönemi" olarak da adlandırdığı kriz öncesi dönem, "olası krizlerin önceden tahmin edilmesi ve gerekli önlemlerin alınması sürecini kapsamaktadır. Bu dönemde işletmeler, en kötü durumlar için kendilerini hazırlamalıdır. Krizden en az hasarla çıkmanın yolu, krize en iyi şekilde hazırlanmaktır". Bu doğrultuda yapılması gerekenler şu şekilde sıralanmıştır (Çiftçi, 2015:58);

- Kriz yönetim planının hazırlanması,

- Kriz yönetim takımının oluşturulması,

- Erken uyarı sistemlerinin kurulması ve izlenmesi,

- İç ve dış çevre analizlerinin yapılması,

- Kriz senaryolarının hazırlanması,

- Kriz iletişim planlarının hazırlanması,

- Personelin kriz yönetimi konusunda bilgilendirilmesi ve eğitilmesidir.

Kriz öncesi dönemde doğru yönetim politikalarını uygulayan örgütler, kriz işaretlerini takip etmeleri ve doğru yönde hareket etmeleri sayesinde ya krize hiç yakalanmazlar ya da krizin olumsuz etkilerini başarılı bir şekilde minimize ederler. Bununla beraber, kriz öncesi süreçte uygulanması gereken politikaları hayata geçirmeyen işletmelerde kriz döneminin ilk kademesi olan "körlük" başlar. Bu süreçte işletmenin krizi tanıyıp ciddiye alması ve kriz sinyalleri sebebiyle düşen işletme içi performansı arttırıp yükselen kaygı seviyesini düşürmesi gerekmektedir. Olumsuz değiş̧ime müdahale edilerek değişimin yönü çevrilmelidir. Bu aşamada işletme yaklaşan krizi göremediği için harekete geçmez veya geçemez. Bu durumda işletmeler "eyleme geçememe" kademesine geçer. Bu dönemde işletme içi performansta düşüş görülür. Yöneticiler mevcut yönetim anlayışının başarılı olacağını ve krizin kendi kendine geçeceğini düşünerek eyleme geçmekten imtina ederler. Sonuç olarak bu durum işletmeleri "yanlış eylem" kademesine götürür. Bu süreçte işletmede gerilim artar, bilgi akışında 
eksiklik ve alınan kararların niteliğinde bozulmalar görülür. Hatalı ve niteliksiz kararlar yanlış eylemlerin hayata geçirilmesine yol açacağ için artan karmaşa ve huzursuzluk işletmeleri krizin eşiğine getirir (Şahin, 2005:3637). Kriz ortaya çıktığ 1 andan itibaren, örgütlerin üzerinde bir korku, karmaşa, endişe ve belirsizlik bulutunun belirmesi muhtemeldir. Örgüt yöneticilerinin bu olasıllğın önüne geçmek için yapmaları gereken, bilinmezlikten ve bilgisizlikten kaynaklanan korkunun ve endişenin oluşmasını engellemektir. Dolayısıyla kriz öncesi dönemde ne kadar çok tedbir alınır, planlama yapılır, olası senaryolar üzerinde çalışıır, iletişim planları hazırlanırsa, krizler önlenebilir veya kriz dönemleri mümkün olan en az hasarla atlatılabilir.

\subsubsection{Kriz Dönemi}

Kriz dönemine geçiş; kriz öncesi dönemde alınması gereken tedbirlerin ihmal edilmesi, krize maddi ve manevi olarak hazırlanılmaması, körlük, eylemsizlik ve yanlış eylem sonucu gerçekleşmektedir. Çakmak (2018:28)'a göre;

"Örgüt içerisinde ya da dışarısında yaşanan olağan dışı olaylar, örgüte fiili zarar vermeye başladı̆̆ krizden kaçma ya da onu başlamadan yok etmeye yönelik davranışlar yerini kriz an yönetimine bırakacaktır. Kriz anı yönetiminde temel amaç, kriz sebebi ile meydana gelmesi olası zararın sinırlandırılması ya da azaltılmasına yönelik girişimlerde bulunup krizin örgüt içerisinde yayılmasinı engellemektir."

Kriz döneminde krize etkin bir mücadele vermek isteyen örgütlerin yapması gerekenler şunlardır;

- Krizin Boyutlarını Belirlemek: Krizin boyutlarını belirlemek için yapılması gerekenler krizin etki değerini hesaplamak ve kriz barometresi oluşturmaktır. Krizin etki değerini hesaplarken mümkün olan en kötü olay tasarlanır. Bu doğrultuda '0'dan '10'a kadar değerler kullanılarak krizin etkisi ifade edilir. Burada ' 0 ' etki olarak en yüksek, ' 10 ' ise en düşük değer kabul edilir. Değerin hesaplanması için, "Krizin şiddeti artarak yükseliyorsa bu şiddete ne kadar dayanabilirsiniz?”, "Medyanın, devletin, ilgili kurumların krizle ilgilenme boyutu nedir?", "Kriz ile rutin faaliyetlerin kesintiye uğrama boyutu nedir?", "Kriz işletmenin kamuoyu imajını ne ölçüde tehlikeye sokmaktadır?" ve "Kriz işletmede ne boyutta hasar yaratır?" soruları sorulur ve bu sorulara söz konusu değerler ile cevaplar verilerek elde edilen sonuç soru sayısına bölünür. Elde edilen sonuç krizin işletme üzerindeki etkisini gösterecektir. Kriz etki ölçeğine yatay olarak eklenen bir doğru ile kriz barometresi oluşturulur. Kriz barometresi krizin olasılık doğrusudur ve kriz etki ölçeği ile kriz barometresinde işaretlenen değerlerin kesiştiği nokta, krizin rengini ifade eder. Bu kesişim noktası, krizin ne derece önemli olduğunu gösterir. Sonrasında yapılması gereken, krizin boyutunu dikkate alır krizi çözmek için müdahale edilip edilmeyeceğine karar vermektir (Ofluoğlu ve Misırl1, 2001:16-18).

- Kriz Yönetim Planı Yapmak: Kriz yönetim planı yapmanın en önemli koşulu; planı kriz kendisini gösterdiğinde yani kriz anında değil, kriz öncesi dönemde yapmaktır. Bu sayede kriz anındaki ilk sarsıntı mümkün olduğunca az bir zararla atlatılabilecektir. Kriz planı yapmak için ilk olarak mevcut vaziyetin analizi yapılmalıdır. Analiz sonucunda işletmenin durumu saptanabilir. Bu aşamada dış faktörler dikkatlice takip edilmeli, iç faktörlerdeki eksiklikler tespit edilerek zayıf yönler güçlendirilmelidir (Arslan, 2013:69). Kriz yönetim planı yapılırken bütüncül bir yöntem izlenmeli, yönetici ve çalışanların koordinasyonu ve iş birliği test edilmeli, muhtemel bir kriz anında hangi işin kim tarafından, nerede, nasıl ve ne amaçla yapılacağı belirlenmelidir.

- Personel Politikası Belirlemek: Krizin boyutları belirlenip kriz yönetim planı oluşturulduktan sonra yapılması gereken personel politikasını belirlenmesidir. Kriz sürecinde insan kaynağı en önemli kaynaklardan birisi olsa da örgütler küçülmeye ve personeli işten çıarma yoluna gidebilirler. $\mathrm{Bu}$ seçenek, motivasyon düşürücü olması sebebiyle en son düşünülmesi ve uygulanması gereken seçenektir (Çakmak, 2018:28). Örgütlerin hâlihazırda bir personel politikaları olmak zorundadır ancak kriz süreçleri olağan dışı süreçler olduğu için kriz durumlarında, olağan zamanlardaki politikaları yürütmek zorlaştığı için kriz dönemlerine yönelik personel politikalarının planlanması gerekmektedir. Yapılabilecek en doğru şey, personelin krizden en az seviyede etkilenmesini sağlamaktır çünkü kriz öncesinde ve kriz döneminde olduğu kadar, kriz sonrasında da en çok ihtiyaç duyulacak olan personeldir. 


\subsubsection{Kriz Sonrası Dönem}

Kriz sonrası dönem, krizin sarsıcı ve yıkıcı etkilerinin bittiği ve kronikleşen krizin sona erdiği dönemdir. Bu dönemde yapılması gerekenler şu şekilde ifade edilmiştir (Çitekçi, 2016:97);

"Örgütler krizin sonuna geldiğinde ve bütün olumsuzluklardan arındığında, var olan kriz yönetim planı tekrar gözden geçirilerek gerekli değişiklikler yapılmalı. Bununla beraber muhtemel bir kriz öncesi, devreye sokulacak yeni kriz planlarının işlevselliği de arttırılmalıdır."

Örgüt yöneticileri krizin ardından bir araya gelerek yaşanan süreci ele almalı ve kapsamlı olarak değerlendirmelidirler. $\mathrm{Bu}$ doğrultuda ifade edildiği üzere; "Kriz bittikten sonra gerçekleştirilen bu değerlendirme sürecine gözden geçirme aşaması denir. Bu aşamada yaşanmış olan krizin neden ortaya çıktı̆̆ına, ileride benzer krizlerin yaşanması durumunda neler yapılabileceğine dair fikir edinmek amaçlanır" (Özhasar ve Eğe, 2019:56).

Kriz Sonrası Uyum Süreci veya Denge Durumuna Dönüş olarak da adlandırılan kriz sonrası dönem, örgütün yaşananları gözden geçirmesi, kriz öncesindeki faaliyetlerine geri dönmesi için yeniden yapılanması (reorganization), var olan kriz yönetim planları ve olasılık senaryolarını gözden geçirmesi, işlemeyen kriz yönetim planlarını yerine yenilerinin getirilmesi, kısa ve uzun vadeli planların yapılması, yöneticilere ve çalışanlara eğitimler verilmesi, kriz sürecinde merkezileşen otoritenin terk edilmesi ve demokratik işleyişe dönülmesi, kriz sürecinde yitirilen karş1lıklı güven ve özgüvenin yeniden tahsis edilmesi gereken dönemdir.

Kriz sonrasında örgütün içinde görülen olumsuz etkilerin yok edilmesi ve yepyeni bir gelişim döneminin başlatılması için yapılması gerekenler şu şekilde sıralanmıştır (Dallaryan, 2006:27);

- Sistemli bir eğitim süreci başlatılarak tüm personelin eğitim konusundaki eksiklikleri giderilir.

- Yönetici pozisyonundaki çalışanlara yönelik geliştirme çalışmaları yapılır, çalışma ortamları ve şartları iyileştirilerek performansa dayalı ödüllendirme yapılır.

- Yönetici olmayan personelin yeni beceriler kazanması ve bu becerileri uygulaması sağlanır.

- Kriz dönemine yönelik değerlendirme yapılarak kriz yönetim ekibini örgüt içi geliştirme ve iyileştirme ekibine dönüştürülür.

- Uzun vadede verimli ve etkin bir kriz yönetimi için vizyon ve misyon çalışmaları yapılır.

\subsubsection{Kriz Yönetimi Yaklaşımları}

Çakmak'a (2018:22) göre krizler, genel yapı itibari ile birbirine belirli ölçüde benzeyen farklı dinamiklere sahip sorunlar olarak örgütlerin ve sistemlerin karşısına çıkmaktadır. Bu sürekli değişen yapının çözüme ulaşma süreci geciktikçe verdiği zarar artmakta, sistemin hayatını giderek daha fazla tehlikeye sokmaktadır. Gündüz (2020:35)'e göre ise krizin göz göre göre ortaya çıktığını gördükten sonra "Evet, kriz yaşlyoruz", sözünü söyleyip o andan itibaren bir şeyler uygulamaya başlamak geç kalmanın bir belirtisidir. Krizlerde, işletmelerin kuruluşundan çöküşüne kadarki tüm süreçlerde yaşanabilme potansiyeli olduğunun bilinmesi ve "Biz önlemimizi şimdiden alalım" bakış açısı ile hareket edilmesi gerekliliğinin belirlenmesi oldukça önemlidir.

\subsubsection{Proaktif (Önleyici) Yaklaşım}

Proaktif yaklaşım, krizlerin oluşabilme ihtimalini göz önüne alarak gerekli tedbirlerin alınması temeline dayanmaktadır. Bu yaklaşımın içeriğinde; önleyici planlamalar ve ofansif (saldırgan) bir şekilde uygulanan stratejiler yer almaktadır. Proaktif yaklaşımlar, küresel ve sektörel bazdaki çevresel değişmelerin hızlı bir şekilde takip edilmesi, öngörücü ve koruyucu faaliyetlerin geliştirilmesi ve temel stratejilere göre uygulamaların esnetilerek, önleyici planlamaların yapılmasını sağlamaktır (Aksu, 2010:68; Gündüz, 2020:36). Tağraf ve Arslan (2003:149-160)'a göre kriz yönetiminde proaktif yaklaşım geliştirmek için aşağıdaki unsurların kullanılması gerekmektedir;

- Doğru ve yeterli bilgi akışını sağlamak,

- Göze alınacak risk miktarını belirlemek,

- Erken uyarı sistemleri oluşturmak, 
- Krize karşı önleyici planlama yapmak,

- Planları yazıya dökmek,

- Fedakârlık miktarını belirlemek,

- Kriz önleme takımları oluşturmak.

\subsubsection{Reaktif (Tepkisel) Yaklaşım}

Reaktif yaklaşım, "örgütlerin genel yönetim biçiminde var olan ve kriz durumunda belirgin bir şekilde ortaya çıkan 'Kriz çıktı şimdi ne yapalım?' sorusunun yanıtını ivedilikle arayan bir yönetim türüdür' (Çakmak, 2018:23). Proaktif yaklaşımda uygulanan stratejiler ne kadar ofansif ise reaktif yaklaşımda o kadar defansiftir. Reaktif yaklaşımda temel amaç, kriz durumuna geçildikten sonra ortaya konulan tepkiler ile krizin vereceği zararı en aza indirmek ve kriz durumundan mümkün olan en kısa zamanda çıkmayı sağlamaktır. Soysal vd.'ne göre reaktif yaklaşım her ne kadar yaygın olarak kullanılsa da proaktif yaklaşım günümüz örgütlerinde daha geçerlidir çünkü Proaktif yaklaşımla örgütler önceden alınan tedbirler ile muhtemel krizlerin etkilerini mümkün olduğu kadar azaltmayı başarabilmektedirler (Soysal vd., 2009:440).

\subsubsection{3. İnteraktif (Etkileşimci) Yaklaşım}

İnteraktif yaklaşım, kriz yönetimi sürecindeki tüm aşamaları bütüncül bir biçimde ele almaktadır. Bu yaklaşımın amac1; kriz yönetimi içerisinde yer alan yönetim fonksiyonları ile aynı işleve sahip olması, mevcut ve muhtemel kriz durumlarının engellenmesi ve çözüme kavuşmasını, normal duruma dönülmesi, gerekli derslerin çıkarılması ve ileriye yönelik öğrendiklerini uygulayacak bir yap1 oluşturmaktır (Göral, 2014:428; Gündüz, 2020:38). Soysal ve arkadaşları tarafından "ögrenme aşaması" olarak nitelendirilen interaktif yaklaşım, kriz durumu yokken veya kriz yaşandıktan sonra edinilen deneyimlerin bir bütünü olarak kendini gösterir (Soysal vd., 2009:435).

Şekil 1. Kriz Yönetim Modeli

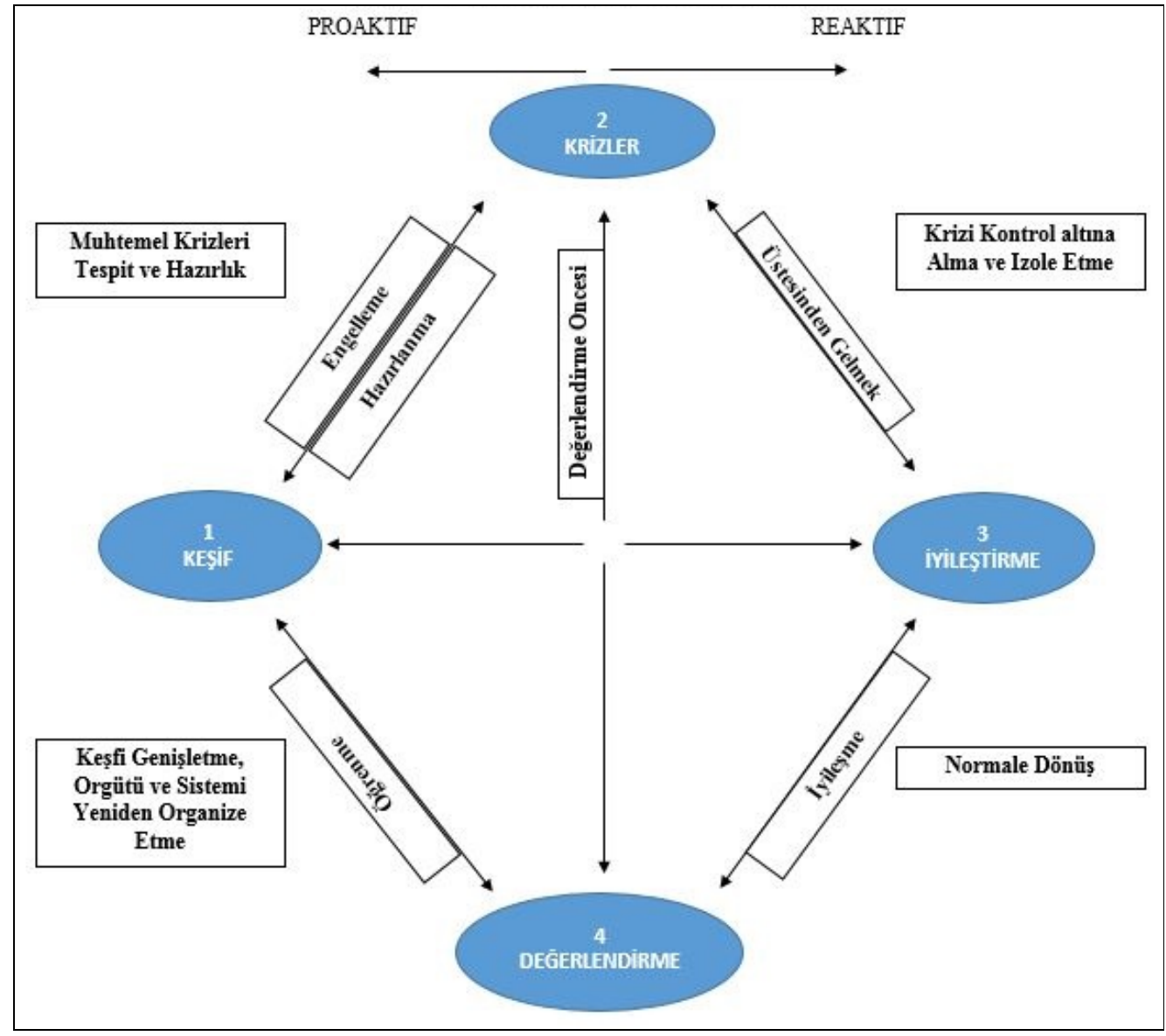

Kaynak: Mitroff vd., 1987:284. 


\subsubsection{Krizin Olumlu Sonuçları}

Krizler her ne kadar örgütlerin varlıklarına yönelik birer tehdit olsalar da krizlerin yapısı ve etkili örgüt yönetimi sayesinde krizlerin olumlu sonuçlarından bahsetmek mümkündür. Krizler, örgütleri bazen yok olma aşamasına kadar getirebilmekte ve telafisi zor kayıplara neden olabilmektedirler. Bununla beraber kriz yönetimi süreçlerini başarıyla geçiren örgütler, krizin ardından birtakım kazançlar elde edebilmektedirler.

Yapılan pek çok çalışmada krizlerin örgütler üzerindeki olumlu etkileri araştırılmış, bu araştırmaların ortak yönleri aşağıdaki gibi özetlenmiştir (Meydan, 2005:40; Roux-Dufort ve Metais, 1999:115; Clair ve Dufrense, 2007:65; Aydemir ve Demirci, 2005:68; Akınc1, 2010:76'dan akt.: Çakmak, 2018:30);

- Örgütün zayıf yönleri ortaya çıkar.

- Örgütsel sorunların ortaya çıkmasını sağlar.

- Yeni rekabet avantajlarını görebilmek açısından bir firsat teşkil eder.

- Sorunlara karşı daha gerçekçi ve etkin stratejiler geliştirilir.

- Örgütün değişime olan direncini kırarak değişme ve yenilenme yönündeki fikirlere daha açık olunacak bir ortam yaratır.

- Paydaşlar ile olan ilişkiler artar, iletişim gelişir.

- Yöneticilerin liderlik özelliklerinin ortaya çıkmasında etkin rol oynar.

- Kalitenin önemi anlaşılır.

- Örgütün misyonu, vizyonu, iklimi, kültürü örgütün öğrenme kapasitesine bağlı olarak yenilenir ya da güncellenir.

- Takım ruhunun oluşması ya da gelişmesine yardımcı bir etki sunar.

- Krizlerden başarılı bir şekilde sıyrılmak pazardaki konumu ve itibarı yükseltecek nitelikte bir imaj sağlar.

- Örgütlere öğrenme, büyüme ve uluslararasılaşma firsatları tanır.

- Kriz deneyimi artar.

\section{COVID-19 HASTALIĞININ DÜNYA VE TÜRKIYY TURIZMINE ETKILERİ}

2019 yılı Aralık ayının sonlarında, yakın zamanda görülen pnömoni (halk arasında bilinen adı ile zatürre) olguları Çin'in Wuhan kentindeki Deniz Ürünleri Pazarı ile ilişkilendirilmiş, 31 Aralık 2019'da Wuhan Sağlı Komisyonu, Çin Halk Cumhuriyeti Ulusal Sağlık Komisyonu ve Çin Halk Cumhuriyeti Hastalık Kontrol ve Korunma Merkezi tarafından yeni bir salgının ortaya çıktığı dünyaya ilan edilmiştir. Hastalık Kontrol ve Korunma Merkezi tarafından, söz konusu salgının sebebi olarak yeni bir koronavirü̈s'ten bahsedilmiş ve 13 Ocak 2020'de resmen duyurulmuştur. İlk etapta 2019-n-Cov olarak adlandırılan Yeni Koronavirüs, sonrasında SARS-CoV-2 adını almıştır (Er ve Ünal, 2020:2; T.C. Sağlık Bakanlığı, https://covid19.saglik.gov.tr/). Hastalığın tanımlanmasının ardından geçen süre sonunda, 11 Şubat 2020'de Dünya Sağlık Örgütü (World Health Organization) tarafından Covid-19 olarak adlandırılmıştır. Dünya Sağlık Örgütü, virüsün yayılma hızının da etkisiyle 11 Mart 2020 tarihinde Covid-19'u pandemi (küresel salgın) ilan etmiştir (Sürme, 2020:9). Gül ve Çelebi (2020:1704) koronavirüsleri;

"İnsanların, hayvanların, kuşların, yarasaların, farelerin ve diğer birçok vahşi hayvanın solunum, karaciğer ve merkezi sinir sistemlerini etkileyen koronavirüsler, insanlarl ve diğer omurgal hayvanları birlikte enfekte eden bir virüs grubudur. Koronavirüsler soğuk alginlı̆̆ olarak bilinen genellikle hafif akut solunum yolu hastallklarına neden olan yaygın insan patojenleridir",

şeklinde tanımlamışlardır. Sürme (2020:12)'ye göre koronavirüsler;

"Soğuk algınlı̆̆l gibi toplumda yaygın görülen, kendi kendini sinırlayan hafif enfeksiyon tablolarından, Orta Doğu Solunum Sendromu (Middle East Respiratory Syndrome, MERS) ve Ağır Akut Solunum Sendromu (Severe Acute Respiratory Syndrome, SARS) gibi daha ciddi enfeksiyon tablolarına neden olabilen büyük bir virüs ailesidir." 
Koronavirüsler, insanlar, diğer memeliler ve kuşlar arasında yaygın olarak dağılan ve solunum, enterik (bağırsaklar ile ilgili), hepatik (karaciğer ile ilgili) ve nörolojik (beyin ile ilgili) hastalıklara neden olan zarflı RNA virüsleridir (Zhu vd., 2020:727; Gül ve Çelebi, 2020:1704). Hastalığın 2-14 gün süren bir kuluçka süresi olup, yüksek ateş (39 derece ve üzeri), öksürük, nefes darlığı, ishal gibi belirtileri vardır. Hastalıktan en ağır şekilde etkilenenler çoğunlukla 65 yaş ve üzerinde ve kronik rahatsızlıkları (kanser, organ yetmezlikleri, diyabet, akciğer ve karaciğer hastalıklart) olan insanlardır.

\subsection{Dünyada ve Türkiye'de Covid-19}

Koronavirüs çok kısa bir sürede dünyaya yayılmış ve birçok ülkeyi etkisi altına almıştır. Salgın insanlarda çok büyük bir kaygı ve korku yaratmış, salgının ilk dönemlerinde hastalıkla ilgili kesin ve net bilgilerin olmayışı insanlardaki kaygıyı ve korkuyu arttırmıştır. Yerel ve uluslararası örgütlerin salgınla ilgili paylaştığı bilgiler ve haberlerin artması insanlar üzerinde olumlu etki yaratsa da bu ölümcül hastalığı ortadan kaldıracak bir ilacın veya aşının olmaması, korkunun ve endişenin devam etmesine neden olmuştur.

Geçmişteki salgınlarla günümüzdeki salgınları kıyasladığımızda aradaki en büyük farkın yayılma ve bulaşma hızı olduğunu görmekteyiz. Bunun temel nedeni insan hareketliliğinin geçmişe oranla büyük bir artış göstermesidir. Küreselleşme sayesinde ulaşımın kolaylaşması ve seyahatlerin artması, Çin'de başlayan salgının dünyanın birçok bölgesine hızlıca yayılmasına sebep olmuş, ülkeler sınırlarını kapatarak şehirleri karantinaya almış, insanlar evlerine kapanmış ve gündelik hayat durmuştur (Turan ve Çelikyay, 2020:4).

Türkiye ilk vaka bildirimini 10 Mart 2020 gecesi yapmıştır. Türkiye'de Covid-19 kaynaklı ilk ölüm ise 17 Mart 2020 'de gerçekleşmiştir. Bundan sonraki süreçte dünyada ve Türkiye'de salgınla mücadele ve kriz yönetimi kapsamında bir dizi düzenleme hayata geçmiş ve önlemler alınmaya başlanmıştır. Virüs özellikle kalabalık ortamlarda, insanların birbirlerine yakın temas etmesi, hapşuruk ve öksürük yollarıyla bulaştığ için insanlara ilk olarak "sosyal mesafe" çağrısı yapılmıştır. Başta sağlı olmak üzere, eğitim, din, askeri, hukuki, ekonomik ve sosyal alanlarda acil tedbirler alınmıştır (T.C. Sağlık Bakanlığı, 2020). Bu çalışmanın hazırlandığı 12 Aralık 2020 tarihinde dünyada (Türkiye dâhil 220 ülke DSÖ’ne rapor sunmaktadır) ve Türkiye'deki güncel Covid-19 vaka-ölüm sayıları Tablo 1'de gösterilmiştir;

Tablo 1. Dünyada ve Türkiye'de Covid-19 Vaka Durumu*

\begin{tabular}{|c|c|c|}
\hline VAKA DURUMU & DÜNYA GENELI & TÜRKIYE \\
\hline Vaka Sayı1 1 & 69.521 .294 & 1.809 .809 \\
\hline Vefat Say1s1 & 1.582 .674 & 16.199 \\
\hline
\end{tabular}

* 12 Aralık 2020 tarihine ait verilerdir.

Kaynak: Dünya Sağlık Örgütü, 2020; T.C Sağlık Bakanlığı, 2020

Covid-19 salgını uluslararası örgütlerce resmen ilan edildikten sonra ülkeler art arda önlemler almaya başlamışlardır. Kriz yönetimi kapsamında değerlendirilebilecek olan birçok tedbir ve düzenlemeyi, salgın ve kriz yönetimi sürecini de ifade ettiği için, aşağıdaki gibi özetleyebiliriz;

- Çin'de başta Wuhan kenti olmak üzere birçok bölgede katı karantina uygulamaları başladı.

- ABD'de acil durum ilan edildi.

- İspanya ve İtalya gibi turistik ülkelerde karantina uygulamaları başladı, Fransa'da sokağa çıkma yasağı ilan edildi.

- Avrupa Futbol Şampiyonası, Eurovision Şarkı Yarışması ve Yaz Olimpiyatları 2021 yılına ertelendi.

- Havayolu işletmeleri salgının yoğun olduğu ülkelere olan seferlerini iptal etti.

- Vaka sayılarının yüksek olduğu ülkelerde eğitime ara verildi ve uzaktan eğitim modeline geçildi.

- Kamu personelleri için mesai saatlerine düzenleme getirildi, uzaktan çalışma imkânı olan kurumlar ve işletmeler uzaktan çalışma modeline geçti.

- Dünyanın birçok ülkesinde ve Türkiye'de de Mart 2020 - Haziran 2020 dönemleri arasında zaman zaman sokağa çıkma yasakları uygulandı.

- İnsanların kalabalık halinde ibadet ettiği mekânlar (başta Vatikan ve Kâbe) kapatıldı. 
- Yerel ve uluslararas1 etkinlikler (toplant, fuar, kongre, konser, festival vb.) iptal edildi veya ertelendi.

- Dünya Sağlık Örgütü’nün yayınladığı bilgilendirmelerle dünya genelinde sosyal mesafe, maske kullanımı, dezenfektan kullanımı ve temizlik ile ilgili uygulamalar başladı.

- Ülkeler, virüsün yayılmasını önlemek için Mart 2020 - Şubat 2020 döneminde havayolu trafiğini azaltarak durma noktasına getirirken bir yandan da komşularıyla sınırlarını kapatarak karayolu trafiğini de sonlandırdılar.

- Yurtdışından gelen vatandaşlar için 14 günlük karantina uygulaması yapıldı. Bu kişilerin 14 gün boyunca izole olmaları sağlandı.

- Yaygın Covid-19 testi uygulamasına geçilerek belirti gösteren kişilere test yapıldı.

- Ülkeler, sokağa çıkma yasağı ve sıkı karantina dönemlerinde kapanmak zorunda kalan işletmeler ve çalışanlar için ekonomi destek paketleri ve yardımlar sağladı.

- Ülkeler Mart 2020 - Haziran 2020 döneminde bir dizi düzenlemeyi hayata geçirerek salgının etkisini azaltmaya çalışmışlardır. Haziran 2020 itibariyle dünyada ve Türkiye'de 'Normalleşme"' adımları atılmaya başlanmıştır.

- Sokağa çıkma yasakları ve kısıtlamaları azaltılarak sonlandırılmıştır.

- Hava, kara ve deniz yolu ulaşımı tekrar faaliyete geçmiştir.

- Sosyal mesafe, maske ve hijyen konularında bilinçlendirme çalışmaları ve uyarılar yapılmıştır.

- Kamu kurumları ve özel işletmelerde, toplu taşıma araçlarında ve kamusal alanlarda maske takma zorunluluğu ile sosyal mesafe uygulamasına geçilmiştir.

- Uzaktan eğitim uygulaması sona erdi ve yüz yüze eğitim modeline geri dönüldü.

- Toplu etkinliklere kişi sayısı sınırlaması getirildi. Sınırlı etkinlikler pandemi kuralları çerçevesinde yapild1.

- Normalleşme sürecinin başlamasıyla dünyada ve Türkiye'de hayat her ne kadar eskisi gibi normal olmasa da yeni normal ile birlikte bazı k1sitlamalar ve zorunluluklar hayatımıza girdi.

$\mathrm{Bu}$ çalışmanın hazırlandığı Kasım - Aralık 2020 dönemine kadar normalleşme dönemi devam etmiştir ancak vaka ve ölüm sayılarının salgının ilk dönemlerinin de üstüne çıkması neticesinde Türkiye'de yeni tedbirler ve düzenlemeler hayata geçirilmeye başlanmıştır. $\mathrm{Bu}$ düzenlemelerin başında kısmi sokağa çıkma yasakları gelmektedir. Türkiye'de hafta içi günlerde saat 21.00 'den 05.00 'e kadar, hafta sonu için ise Cuma günü saat 21.00'den Pazartesi günü saat 05.00'e kadar kısmi sokağa çıkma kısıtlaması uygulanmaktadır.

Tablo 2. Dünya Genelinde En Yüksek Vaka Sayısına Göre 20 Ülke*

\begin{tabular}{|c|c|c|c|c|}
\hline ÜLKE & $\begin{array}{c}\text { TOPLAM } \\
\text { VAKA } \\
\text { SAYISI }\end{array}$ & $\begin{array}{c}\text { SON 24 SAATTE } \\
\text { BİLDIRILEN } \\
\text { VAKA SAYISI }\end{array}$ & $\begin{array}{c}\text { TOPLAM VEFAT } \\
\text { SAYISI }\end{array}$ & $\begin{array}{c}\text { SON 24 SAATTE } \\
\text { BİLDIRILEN } \\
\text { VEFAT SAYISI }\end{array}$ \\
\hline ABD & 15.404 .889 & 201.681 & 290.133 & 2.749 \\
\hline HINDİSTAN & 9.826 .775 & 30.006 & 142.628 & 442 \\
\hline BREZILYA & 6.781 .799 & 53.347 & 179.765 & 770 \\
\hline RUSYA & 2.597 .711 & 28.585 & 45.893 & 613 \\
\hline FRANSA & 2.297 .425 & 13.673 & 56.572 & 292 \\
\hline İNGILTERE & 1.787 .787 & 20.964 & 63.082 & 516 \\
\hline İTALYA & 1.787 .147 & 16.988 & 62.626 & 387 \\
\hline İSPANYA & 1.720 .056 & 7.955 & 47.344 & 220 \\
\hline ARJANTIN & 1.483 .376 & 8.154 & 40.442 & 176 \\
\hline KOLOMBIYA & 1.399 .911 & 7.778 & 38.484 & 598 \\
\hline ALMANYA & 1.272 .078 & 29.875 & 20.970 & 671 \\
\hline MEKSIKA & 1.217 .126 & 11.897 & 112.326 & \\
\hline
\end{tabular}




\begin{tabular}{|c|c|c|c|c|}
\hline POLONYA & 1.102 .096 & 9.594 & 51.728 & 232 \\
\hline İRAN & 1.092 .617 & 9.594 & 51.728 & 232 \\
\hline PERU & 979.111 & 1.799 & 36.499 & 44 \\
\hline TÜRKIYE & 1.809 .809 & 30.424 & 16.199 & 222 \\
\hline UKRAYNA & 872.228 & 13.514 & 14.755 & 285 \\
\hline G. AFRIKA & 836.764 & 8.166 & 22.747 & 173 \\
\hline ENDONEZYA & 605.243 & 6.310 & 18.511 & 6 \\
\hline BELÇIKIA & 600.397 & 3 & 17.692 & 6 \\
\hline
\end{tabular}

Kaynak: Dünya Sağlık Örgütü, 2020; T.C Sağlık Bakanlı̆̆ı, 2020

* 12 Aralık 2020 tarihine ait değerlerdir.

Tablo 2'de dünya genelinde toplam vaka sayısına göre ülkelerin durumu ve Türkiye'nin bu ülkeler arasındaki yeri sunulmuştur.

\subsection{Covid-19 Krizinin Dünyada ve Türkiye'de Turizme Etkileri}

Krizler, birçok olumsuz etkiler doğuran beklenmedik olaylardır. Örgüt içi faktörlerden kaynaklı krizlerle beraber sektörlere kötü yönde etki eden büyük ölçekli krizler de yaşanmaktadır. Turizm sektörü üzerinde olumsuz etkisi olan kriz sebeplerine örnek olarak ekonomik ve finansal sorunları, doğal afetleri, terör saldırılarını, sosyo-kültürel olayları ve siyasi sorunları verebiliriz. Bununla beraber salgın hastalıklar da birer kriz sebebidir. Salgın hastalıkları krize sebep olan dış faktörlerden "biyolojik faktörler" kategorisine yerleştirmek mümkündür. Bir destinasyonun turistik çekiciliğini yitirmesine sebep olan başlıca faktörlerden bir tanesi salgın hastalıklardır çünkü insanlar için en temel ihtiyaç ve talep güvenliktir (Çeti ve Ünlüönen, 2019:110).

Covid-19 krizi, beraberinde getirdiği zorunlu düzenlemeler neticesinde dünya genelinde turizm faaliyetlerine çok büyük bir darbe vurmuştur ve bu darbenin etkisi devam etmektedir. Turizm, yaklaşık 60 sektörü doğrudan, 185 sektörü de dolaylı olarak etkilemektedir. Bu açıdan turizm, en rekabetçi ve en çok döviz kazandıran sektör konumundadır. Toplam istihdamın \%8'ini oluşturan turizm, en çok istihdam yaratan ve alt yapı sektöründen sonra en yaygın ikinci sektördür (Bahar ve Çelik İlal, 2020:126).

Turizm son derece hassas ve kırılgan bir sektördür. Turistik ürünlerin üretildikleri yerde tüketilmesi, turizmin emek-yoğun bir hizmet sunması, turistik ürünün stoklanamaz olması, en temel ihtiyaç olan güvenlik algısının turistlerin destinasyon tercihinde büyük rol oynaması, otomasyona gidilemeyen ve bu nedenle büyük oranda insan odaklı bir sektör olması turizmin hassas ve kırılgan bir sektör olmasının temel sebepleridir. Örneğin 11 Eylül saldırıları sonrasında Amerika'ya yönelik güvenlik algısında bir kırılma olmuş ve o dönem havayolu seyahatlerinde ve dolayısıyla ziyaretçi sayılarında azalma olduğu gözlenmiştir.

Turizm üzerinde etkili olan krizlerin çoğunlukla dış faktörlerden kaynaklandığını (terör, doğal afet, salgın hastalıklar, ekonomik krizler vb.) söyleyebiliriz. Yaşanan olaylar neticesinde turizm faaliyetleri azalmakta, destinasyonlara olan talep düşmekte, ülkelerin pazar payı azalmakta, turizm harcamalarında düşüş yaşanmakta, turizm yatırımları durmakta, destinasyonların imajı zarar görmekte, bölgesel kalkınma durma noktasına gelmekte, istihdam oranı azalmakta, turizm çalışanları işinden olmakta ve bunlar yeni krizlerin ortaya çıkmasına sebep olmaktadir.

Covid-19'un en çok etkilediği sektörlerden olan turizmde, 2020 yılı sonunda yaklaşık 1,2 trilyon \$ kayıp yaşanması beklenirken, uluslararası turist sayısında ise 850 milyon ile 1,1 milyar arasında kayıp (2020'nin ilk 8 ayına göre ve 2019'un aynı dönemi ile kıyaslandığında \%70'lik bir düşüş) beklenmektedir. Yaklaş1k 120 milyon turizm çalışanının ise işini kaybedeceği tahmin edilmektedir (Birleşmiş Milletler Dünya Turizm Örgütü UNWTO, 2020).

Uluslararası seyahat oranlarına bölgesel olarak baktığımızda; 2019 yılı ile kıyaslandığında 2020'nin ilk 8 aylık döneminde Asya-Pasifik'te \%79, Afrika'da \%69, Orta Doğu'da \%69, Avrupa'da \%68 ve Amerika'da \%65 oranında azalma gerçekleşmiştir. 
TOKTAŞ, Yusuf - Covid-19 Sürecinde Kriz Yönetimi: Türkiye’de Turizm İşletmelerine Yönelik Düzenlemeler

Tablo 3. 2015 - 2020 Yılları Arasında Türkiye’ye Gelen Ziyaretçiler

\begin{tabular}{|c|c|c|c|c|c|c|}
\hline Y1llar & $\begin{array}{c}\text { Yabanc1 } \\
\text { Ziyaretçi } \\
(\mathrm{A})\end{array}$ & $\begin{array}{c}\text { Değişim Oranı } \\
\%\end{array}$ & $\begin{array}{c}\text { Yurtdışı İkametli } \\
\text { Ziyaretçiler } \\
(\mathrm{B})\end{array}$ & $\begin{array}{c}\text { Değişim } \\
\text { Oranı } \\
\%\end{array}$ & $\begin{array}{c}\text { Toplam } \\
\text { Ziyaretçi } \\
\text { (A+B) }\end{array}$ & $\begin{array}{c}\text { Değişim } \\
\text { Oranı } \\
\%\end{array}$ \\
\hline 2015 & 36244632 & $-1,61$ & 4869437 & 1,67 & 41114069 & $-1,23$ \\
\hline 2016 & 25352213 & $-30,05$ & 5554467 & 14,07 & 30906680 & $-24,83$ \\
\hline 2017 & 32410034 & 27,84 & 5559790 & 0,10 & 37969824 & 22,85 \\
\hline 2018 & 39488401 & 21,84 & 6624191 & 19,14 & 46112592 & 21,45 \\
\hline 2019 & 45058286 & 14,11 & 6688913 & 0,98 & 51747199 & 12,22 \\
\hline $2020 *$ & 9458589 & $-74,03$ & 2451749 & $-52,27$ & 11910338 & $-71,34$ \\
\hline
\end{tabular}

Kaynak: Türkiye İstatistik Kurumu (TÜİK), 2020; Kültür ve Turizm Bakanlığı, 2020

Tablo 3'te 2015 yılı itibariyle ülkemize gelen ziyaretçi sayıları sunulmuştur. Son 5 yıl içerisinde Türkiye'ye gelen ziyaretçi sayılarına baktığımızda krizlerin turizm üzerindeki etkilerini net bir şekilde görebilmekteyiz. Öncelikle 2015 ve 2016 yılları arasındaki değişim oranı dikkati çekmektedir. 2016 yılında Türkiye'de gerçekleşen terör saldırıları sebebiyle ziyaretçi oranında dikkate değer bir azalma olmuştur. 2020 yılına gelene kadar arada geçen sürede terör saldırılarından kaynaklı krizlerin etkisi azalmış ve rakamlar yukarıya doğru seyretmeye başlamıştır ancak 2020 yılına geldiğimizde patlak veren Covid-19 krizi, Ocak - Eylül 2020 rakamlarının da ifade ettiği üzere, benzeri görülmemiş bir düşüşe sebep olmuştur.

Tablo 4. Aylara Göre Türkiye’ye Gelen Ziyaretçiler (Ocak - Eylül 2020)

\begin{tabular}{|c|c|c|c|c|c|c|}
\hline Aylar & $\begin{array}{c}\text { Yabanc1 } \\
\text { Ziyaretçi }\end{array}$ & $\begin{array}{c}\text { Bir Önceki Y1lın } \\
\text { Aynı Dönemine } \\
\text { Göre Değişim } \\
\text { Oran1 }(\%) \\
\end{array}$ & $\begin{array}{l}\text { Yurtdışı } \\
\text { İkametli } \\
\text { Ziyaretçiler }\end{array}$ & $\begin{array}{l}\text { Bir Önceki Yılın } \\
\text { Aynı Dönemine } \\
\text { Göre Değişim } \\
\text { Oranı }(\%)\end{array}$ & $\begin{array}{c}\text { Toplam } \\
\text { Ziyaretçi }\end{array}$ & $\begin{array}{c}\text { Bir Önceki Y1lın } \\
\text { Aynı Dönemine } \\
\text { Göre Değişim } \\
\text { Oranı }(\%) \\
\end{array}$ \\
\hline Ocak & 1787435 & 16,11 & 499575 & 8,57 & 2287010 & 14,37 \\
\hline Şubat & 1733112 & 3,76 & 463,341 & 4,43 & 2196453 & 3,90 \\
\hline Mart & 718097 & $-67,83$ & 250440 & $-51,26$ & 968537 & $-67,73$ \\
\hline Nisan & 24238 & $-99,26$ & - & - & 24238 & $-99,36$ \\
\hline Mayıs & 29829 & $-99,26$ & - & - & 29829 & $-99,34$ \\
\hline Haziran & 214768 & $-95,96$ & 81072 & $-87,55$ & 295840 & $-95,04$ \\
\hline Temmuz & 932927 & $-85,90$ & 448877 & $-43,64$ & 1381804 & $-81,36$ \\
\hline Ağustos & 1814701 & $-71,23$ & 377550 & $-46,74$ & 2192251 & $-68,76$ \\
\hline Eylül & 2203482 & $-59,40$ & 330894 & $-40,48$ & 2534376 & $-57,64$ \\
\hline TOPLAM & 9458589 & $-74,03$ & 2451749 & $-52,27$ & 11910338 & $-71,37$ \\
\hline
\end{tabular}

Kaynak: TÜİK, 2020; Kültür ve Turizm Bakanlı̆̆ı, 2020

Tablo 4'te 2020'de aylara göre Türkiye'ye gelen ziyaretçi sayıları sunulmuştur. Covid-19 krizinin Türkiye turizmi üzerindeki etkisini yukarıdaki tabloda yer alan verilere baktığımızda açıcça görebilmekteyiz. Salgından hemen önceki Ocak ve Şubat aylarındaki rakamlar, Türkiye turizminin 2019'da kaydettiği yükselişi sürdüreceğinin işareti olarak göze çarpıyor ancak salgının patlak verdiği Mart ayı ile birlikte çok büyük oranda bir düşüş yaşanmıştır. Seyahatlerin kısıtlanıp turizm faaliyetlerinin durma noktasına geldiği Mart - Haziran döneminde bir önceki yıla göre değişim oranı neredeyse \%100'e dayanmıştır. Ancak kriz yönetimi çerçevesinde ele alabileceğimiz düzenlemelerin hayata geçmesi, kontrollü normalleşme ve yeni normal hayat kuralları ile birlikte Haziran - Eylül döneminde kısmen ve az da olsa düzelme kaydedilmiştir. 
Tablo 5. Y1llara Göre Turizm Gelirleri ve Ortalama Harcama (2015 - 2020)

\begin{tabular}{|c|c|c|c|c|c|c|c|c|}
\hline Y1llar & $\begin{array}{c}\text { Yabanc1 } \\
\text { Ziyaretçi } \\
\text { Turizm } \\
\text { Geliri } \\
(1000 \$)\end{array}$ & $\begin{array}{c}\text { Yabanc1 } \\
\text { Ziyaretçi } \\
\text { Ortalama } \\
\text { Harcama } \\
(\$)\end{array}$ & $\begin{array}{c}\text { Yurtdış1 } \\
\text { İkametli } \\
\text { Vatandaş } \\
\text { Turizm Geliri } \\
(1000 \$)\end{array}$ & $\begin{array}{c}\text { Yurtdış1 } \\
\text { Ikametli } \\
\text { Vatandaş } \\
\text { Ortalama } \\
\text { Harcama }(\$)\end{array}$ & $\begin{array}{c}\text { GSM+Marina } \\
\text { Hizmet } \\
\text { Harcamaları } \\
(1000 \$)\end{array}$ & $\begin{array}{c}\text { Toplam } \\
\text { Turizm } \\
\text { Geliri } \\
(1000 \$)\end{array}$ & $\begin{array}{c}\text { Değişim } \\
(\%)\end{array}$ & $\begin{array}{c}\text { Ortalama } \\
\text { Harcama }\end{array}$ \\
\hline 2015 & 25438923 & 715 & 5843074 & 970 & 182781 & 34464777 & $-8,28$ & 756 \\
\hline 2016 & 15991381 & 633 & 5964853 & 978 & 151206 & 22107440 & $-29,74$ & 705 \\
\hline 2017 & 20222971 & 630 & 5908752 & 903 & 151933 & 26283656 & 18,89 & 681 \\
\hline 2018 & 24028311 & 617 & 5345472 & 801 & 139142 & 29512926 & 12,29 & 647 \\
\hline 2019 & 28704946 & 642 & 5688271 & 796 & 127116 & 34520332 & 16,97 & 666 \\
\hline $2020 *$ & 6167353 & 680 & 1928881 & 886 & 49327 & 8145561 & $-69,4$ & 724 \\
\hline
\end{tabular}

* Ocak - Eylül 2020 (Nisan, Mayıs ve Haziran ayları TÜİK tarafından pandemi nedeniyle hesaplanamamıştır. 2020 yılı değişim oranları bir önceki yılın aynı dönemine göredir.)

Kaynak: TÜIK, 2020; Kültür ve Turizm Bakanlığı, 2020; Türkiye Cumhuriyeti Merkez Bankası (TCMB), 2020.

Tablo 5 'te Türkiye'nin son 5 yılda elde ettiği turizm gelirleri ve ortalama harcama verileri sunulmuştur. Son olarak Tablo 6’da 2020 yılının Ocak - Eylül dönemi, aylara göre turizm gelirleri sunulmuştur.

Tablo 6. Aylara Göre Turizm Gelirleri (Ocak - Eylül 2020)

\begin{tabular}{|c|c|c|c|c|c|c|}
\hline Aylar & $\begin{array}{c}\text { Yabanc1 } \\
\text { Ziyaretçilerden } \\
\text { Elde Edilen } \\
\text { Gelir }(1000 \$)\end{array}$ & $\begin{array}{c}\text { Yabancı } \\
\text { Ziyaretçiler } \\
\text { Ortalama } \\
\text { Harcama (\$) }\end{array}$ & $\begin{array}{c}\text { Yurtdışı İkametli } \\
\text { Vatandaş } \\
\text { Ziyaretçilerden } \\
\text { Elde Edilen Gelir } \\
\text { (1000\$) }\end{array}$ & $\begin{array}{l}\text { Yurtdışı İkametli } \\
\text { Vatandaş } \\
\text { Ziyaretçiler } \\
\text { Ortalama } \\
\text { Harcama (\$) }\end{array}$ & $\begin{array}{l}\text { GSM Dolaşım Hizmetleri } \\
\text { ve Marina } \\
\text { Harcamalarından Elde } \\
\text { Edilen Gelir } \\
\left(1000^{1 / 2}\right)\end{array}$ & $\begin{array}{l}\text { Toplam } \\
\text { Turizm } \\
\text { Geliri } \\
(1000 \$)\end{array}$ \\
\hline Ocak & 1463303 & 708 & 364897 & 787 & 5808 & 1834008 \\
\hline Şubat & 1168804 & 702 & 305180 & 787 & 5462 & 1479447 \\
\hline Mart & 660243 & 729 & 121039 & 796 & 6467 & 787750 \\
\hline Nisan & - & - & - & - & - & - \\
\hline Mayıs & - & - & - & - & - & - \\
\hline Haziran & - & - & - & - & - & - \\
\hline Temmuz & 323196 & 610 & 232624 & 942 & 5589 & 561409 \\
\hline Ağustos & 1125150 & 657 & 488375 & 1016 & 8778 & 1622303 \\
\hline Eylül & 1426656 & 652 & 416764 & 933 & 17223 & 1860644 \\
\hline TOPLAM & 6167353 & 680 & 1928881 & 886 & 49327 & 8145561 \\
\hline
\end{tabular}

* Ocak - Eylül 2020 (Nisan, Mayıs ve Haziran ayları TÜİK tarafından pandemi nedeniyle hesaplanamamıştır)

Kaynak: TÜİK, 2020; Kültür ve Turizm Bakanlığı, 2020; TCMB, 2020.

Tablo 5 ve Tablo 6'ya baktığımızda, tıpkı aylara ve yıllara göre Türkiye'ye gelen ziyaretçi sayılarında olduğu gibi aynı yıllarda ve aylarda düşüşlerin yaşandığı görülmektedir. Azalan ziyaretçi sayısının bir sonucu olarak turizm gelirleri de azalmıştır. Covid-19 krizinin başlangıç dönemi olan Mart, Nisan ve Mayıs aylarındaki gelir kaybı Haziran, Temmuz ve Ağustos aylarında alınan tedbirler, yürürlüğe konulan düzenlemeler, çıkarılan genelgeler, kamu - özel sektör iş birlikleri, kısacası kriz yönetimi düzenlemeleri neticesinde ilgili dönemdeki gelir kaybı hızı yavaşlamıştır ancak geçen yılın aynı dönemine göre gelir kaybı çok yüksektir. 


\section{TÜRKIYE'DE TURIZM IŞLETMELERINE YÖNELIKK COVID-19 DÜZENLEMELERİ}

Covid-19 krizinde, vaka ve vefat sayılarının artmasıyla birlikte hükümetlerin önlemlerini ve düzenlemelerini arttırmaları zaruri olmuştur. Sosyal etkinlikler ertelenmiş veya iptal olmuş, toplu ulaşım araçlarında kişi sayısı kısıtlanmış, şehirlerarası münferit ve toplu ulaşım sınırlandırılmış veya durdurulmuş, ilk etapta 65 yaş ve üzerine sonrasında 20 yaş ve altı kişilere sokağa çıkma yasağı getirilmiş, Mart - Haziran 2020 döneminde 30 büyükşehir ve Zonguldak ilini kapsayan sokağa çıkma yasakları uygulanmış, yurtdışından gelen kişiler 14 gün boyunca devlet yurtlarında karantina altına alınmış ve kamusal alanlarda maske - sosyal mesafe tedbirleri uygulanmaya başlamıştır (Demir vd., 2020:82).

2020 yılının haziran ayı itibariyle, normalleşme süreci ile birlikte öncelikle sokağa çıkma yasakları sonlandırılmış sonrasında ise kontrollü sosyal hayata yavaş yavaş geri dönülmeye başlanmıştır. Bu çalışmanın hazırlandığı Aralık ayına kadar devam eden kontrollü sosyal hayat düzenlemeleri ve tedbirlerinde kısmi sokağa çıkma yasaklarına geri dönülmüştür. Salgın krizinin yönetimi sürecinde turizm işletmelerinin de uymakla yükümlü olduğu birtakım kurallar koyulmuştur. Çalışmamızın bu kısmında, Covid-19 krizi yönetimi kapsamında getirilen kurallar ve düzenlemeler, konaklama, seyahat ve yiyecek - içecek işletmeleri kapsamında incelenmiştir.

Covid-19 krizi yönetimi kapsamında konaklama işletmelerine yönelik alınan tedbirler, düzenlemeler ve kararları aşağıdaki gibi sıralayabiliriz;

- Misafir kayıtlarının (son 14 gün içerisinde bulunduğu ülkeler ve konaklaması sonrasında ülke içindeki seyahat planı dâhil) tam ve düzenli tutulması gerekmektedir.

- Odalar ve diğer kapalı alanlardaki camlar günlük rutin temizlik esnasında açık olmalı, temizlik sonrasında en az 1 saat havalandırılmalıdır.

- Oda temizliğini yapan kişi her oda temizliğinden sonra yeni eldiven giymelidir.

- Havuzların klor düzeylerinin mevzuatta belirlenen seviyede olmasına dikkat edilmelidir.

- Sauna, masaj salonları, spor salonları ve çocuk kulüpleri mümkün olduğunca kullanılmamalıdır. Kullanım durumunda rezervasyonla sinırlı sayıda misafir alınmalıdır.

- Odalarda bulunan klimaların düzenli olarak bakımının yapılması gerekmektedir.

- Konaklama tesislerinde Covid-19 belirtileri gösteren kişiler diğer misafirlerden ivedilikle ayrılıp, maske takması sağlanarak en yakın sağlık kuruluşuna başvurması sağlanmalıdır.

- Covid-19 tanısı konulan misafirin odası 24 saat süreyle havalandırılmalı ve boş tutulmalıdır. Sonrasında detaylıca temizlenerek başka misafirlere tahsis edilmelidir.

- Konaklama tesisinde görevli tüm personele Covid-19 ile ilgili eğitimler verilmelidir.

- Lobi, lavabolar, koridorlar ve asansörler gibi ortak alanlarda el dezenfektanı bulundurulmalı, bilgilendirme afişleri asılmalıdır. Ortak alanlarda sosyal mesafe kuralları uygulanmalıdır (T.C. Sağlık Bakanlığı Covid-19 Salgın Yönetimi ve Çalışma Rehberi, 2020:451).

- Türkiye Turizm Tanıtım ve Geliştirme Ajansı tarafından konaklama, yeme - içme, tur ve transfer araçları, kongre ve sanat tesisleri, temalı parklar ve deniz turizmi tesislerine verilen Güvenli Turizm Sertifikası, oda sayıs1 50 ve üzeri olan (01.01.2021 itibariyle 30 ve üzeri olan) konaklama tesisleri için zorunlu, oda sayıs1 50'den az (01.01.2021 itibariyle 30'dan az) olan konaklama tesisleri ve diğer alanlar için isteğe bağlı olup sertifikayı almak isteyen tesis işletmeleri yetkili uluslararası akreditasyon kuruluşlarına başvuruda bulunabilmektedirler. Bir aylık periyotlarla 1 gün içerisinde yapılan denetimler sonunda verilen sertifika, konaklama işletmesinin Covid-19 tedbirlerine uyumlu olduğunu göstermektedir. Konaklama tesisleri için değerlendirme formunda temel yükümlülükler, misafirin otele girişi, personel için alınacak önlem ve uygulamalar, genel alanlarda düzenlemeler (yatak odaları, mutfaklar, yeme - içme üniteleri, yüzme havuzları ve plajlar, spor salonları ve SPA), güvenlik, otel taşıtları, lojmanlar, atık yönetimi, depolama, acil durum ve izolasyon, tabela, logo, sertifika ve QR kod başlıkları altında kriterler ve kurallar belirlenmiştir ve değerlendirmeler bu kriterlere göre yapılmaktadır (https://tga.gov.tr).

- Sokağa çıkma yasakları ve kısıtlamalar döneminde çalışamayan kişiler için Kısa Çalışma Ödeneği sağlanmıştır. 
- Kültür ve Turizm Bakanlığı'ndan belgeli yatırımcılardan ve işletmelerden 2020'de tahsil edilmesi gereken kira, kesin izin, kesin tahsis, kullanma izni ve yararlanma payları ödemeleri 6 ay ertelenmiştir.

- 1 Ocak 2021'de yürürlüğe girmesi öngörülen konaklama vergisinin yürürlük tarihi 1 Ocak 2022'ye ertelenmiştir.

Covid-19 krizi yönetimi kapsamında yiyecek - içecek işletmelerine yönelik alınan tedbirler, uygulamalar ve kararları aşağıdaki gibi sıralayabiliriz;

- Bu tedbirler restoran, lokanta, kafeler ile içinde yeme-içme hizmet alanı bulunan dinlenme tesisleri, kitapçılar, büfe ve kantinler ile diğer işletmelerin restoran-kafe bölümleri dâhil yeme-içme sektöründeki işletmeler için geçerlidir.

- İşletmeciler tesisin tamamında sosyal mesafe önlemlerini almakla yükümlüdür. Genel kullanım alanlarına ve oturma düzenine ilişkin sosyal mesafe planı hazırlanmalı, misafir kapasitesi bu plana göre belirlemeli, plana uygun misafir kabul edilmeli ve kapasite bilgisi tesisin görülebilir bir noktasına asılmalıdır.

- Tesis giriş holünde veya dış cephesinde ve misafir ile personelin kolayca görebileceği genel kullanım alanlarında, tesiste uygulanan ve uyulması gereken Covid-19 tedbirleri ve kurallarını yer aldığı panolar düzenlenmelidir.

- Misafirlere tesise girişte termal kamera veya temassız ateş ölçümü uygulanmalıdır.

- Tesis girişlerinde el dezenfektanı bulundurulmalı ve misafirler ellerini dezenfekte ettikten sonra tesise kabul edilmelidir.

- Maskesiz misafirler tesise kabul edilmemeli, maskesi olmayanlar için maske bulundurulmalı, yeme-içme faaliyeti dışında ve masadan kalktıklarında maske takmaları sağlanmalıdır.

- Yemek salonları, giriş alanı ve holü, ilave salonlar gibi genel alan kullanımları ve açık alanlar dâhil tesisin tamamı sosyal mesafe planına uygun olarak düzenlenmelidir. Tesis içinde veya dışında sıra oluşabilecek her yerde 1,5 metre ara ile sosyal mesafe sınırlandırmaları yapılmalıdır.

- Masalar arası mesafe her yönden 1,5 metre, yan yana sandalyeler arası $60 \mathrm{~cm}$ olacak şekilde düzenlenmelidir. Masalarda sadece karşılıklı oturma düzeni sağlanmalıdır.

- Her masada el antiseptiği bulunmalıdır.

- Mümkün olduğunca temassız ödeme alınmalıdır. Temaslı pos cihazı kullanılması halinde, her kullanımdan sonra cihazın \%70'lik alkolle silinerek dezenfekte edilmesi gerekmektedir.

- Personelin Covid-19 hakkında bilgilendirilmesi ve bilinçlendirilmesi sağlanmalıdır.

- Bütün personel ağız ve burnu kapatacak şekilde tıbbi maske kullanmalıdır.

- Gıda güvenliği ve mutfak hijyeni uygulamalarının ilgili mevzuat ve yönetmeliklere uygun yapılması sağlanmalıdır.

- Çapraz bulaşmayı önlemek için, işlem görmemiş gıda maddeleri ile hazırlanmış gıdalar mutfakta birbirlerinden ayrı yerlerde muhafaza edilmelidir. Ayrıca, hiçbir gıda maddesi zeminle temas ettirilmemelidir.

- Mutfakta, personelin uyması gereken kurallar ve iyi hijyen uygulamaları ile ilgili görsel/yazılı bilgilendirme yapılmalıdır (T.C. Sağlık Bakanlığı Covid-19 Salgın Yönetimi ve Çalışma Rehberi, 2020:141-146).

- Son olarak, Kültür ve Turizm Bakanlığı tarafından 20 Mayıs 2020 tarihinde yayınlanan Yeme-İçme Tesislerinde Kontrollü Normalleşme Süreci konulu genelge ile yiyecek - içecek işletmelerinde genel ilkeler, misafir kabulü, yemek salonu ve genel kullanım alanları, personel, genel temizlik ve bakım, mutfak ve servis alanları ve işletme araçları ile ilgili uygulamalar tesislere duyurulmuştur (https://www.ktb.gov.tr).

Türkiye'de Covid-19 krizi yönetimi sürecinde hava, kara, deniz ve demiryolu taşımacılığı hizmeti veren işletmelerin uyması gereken kurallar ve uygulamalar aşağıdaki gibi sıralanabilir; 
- T.C İçişleri Bakanlığı tarafından alınan kararla 14 Mart 2020'den 17 Nisan 2020 tarihine kadar Almanya, Avusturya, Hollanda, Belçika, Norveç, İsveç, Danimarka, İspanya ve Fransa ülkelerine mensup vatandaşların Türkiye'ye girişleri kısıtlanmıştır.

- Sağlık Bakanlığı Bilim Kurulu kararlarına göre 21 Mart 2020 itibariyle 46 ülkeye daha uçuşlar durdurulmuştur. 27 Mart 2020 itibariyle diş hat uçuşları durdurulmuştur. 3 Nisan 2020 itibariyle tüm iç hat uçuşları durdurulmuştur (T.C. Ulaştırma ve Altyapı Bakanlığı, 2020).

- Türkiye genelinde uygulanan sokağa çıkma kısıtlamaları süresince şehirlerarası seyahatler de kısıtlanmıştır.

- Kontrollü normalleşme sürecine geçilmesiyle birlikte Hayat Eve Sı̆̆ar (HES) uygulaması da hayata geçirilmiştir. Bu uygulama üzerinden kimlik bilgileri ile alınan kod vasıtasıyla şehirlerarası seyahat yapmak isteyen kişilerin ilgili personele HES kodunu beyan etmesi yeterli olmaktadır.

- Araçların içine Covid-19 ile ilgili uyulması gereken kurallar görünür bir şekilde asılmalı, aracı kullananlar ve yolcuların bu kurallara uyması sağlanmalıdır. Terminaller ve araçlarda Covid-19 ile ilgili önlemlere dair anonslar yapılmalıdır.

- Araçlarda giriş kapısının yanına el antiseptiği konulmalıdır.

- Çalışan personelin Covid-19 ile ilgili bilgilenmesi sağlanmalıdır. Bilet satış ofislerinde, yazıhanelerde, yönetimde çalışan personellerle mümkünse yüz yüze toplantılar veya etkinlikler sınırlandırılmalı, telekonferans veya çevirim içi etkinlikler ve toplantılar yapılmalıdır.

- Araçlara biniş, yolculuk ve inişs süresince maske kullanımı sağlanmalıdır.

- Yolculuk süresince ateş, öksürük, burun akıntısı, solunum sıkıntısı belirtileri gösteren çalışanlar diğer personelden ve varsa yolculardan ayrı bir bölümde izolasyona alınmalı ve tıbbi maske takarak sağlık kuruluşuna yönlendirilmelidir.

- Araçlarda her gün düzenli olarak temizlik yapılmalıdır. Araçların temizliği ve dezenfeksiyonu yolcu kullanımından önce ve sonra yapılmalıdır.

- Mola yerleri, istasyonlar, dinlenme tesisleri vb. yerlerdeki tuvaletlere ve araçta bulunan tuvaletlere el yıkama ve maske kullanımı ile ilgili afişler asılmalıdır.

- Yolcular arasında birer koltuk boşluk bırakılarak seyahat etmeleri sağlanmalıdır.

- Kısa süreli seyahatlerde (2 saat) su dışında yeme - içme yapılmamalıdır.

- Trenlerde yemek vagonu kapalı olmalıdır.

- Sosyal uygulamaların haricinde, iç hat uçuşlarında KDV oranı Haziran 2020 sonuna kadar \%18'den \%1'e indirilmiştir (T.C. Sağlık Bakanlığı Covid-19 Salgın Yönetimi ve Çalışma Rehberi, 2020:157-162).

\section{SONUÇ}

Gerek kamu yönetiminde gerekse özel işletme yönetiminde krizlere her zaman hazırlıklı olmak ve kriz yönetim sürecini bilmek bir tercih değil zorunluluktur. Krizin farkında olmak, krizle mücadeleye hazır olmak, kriz yönetimi yaklaşımlarından işletme için en uygun olanını bulmak, kriz sürecini en iyi şekilde yönetmek, krizin olumsuz sonuçlarını azaltarak krizden olumlu çıkarımlar elde etmek ve olası krizlerin yaşanmasını engellemek günümüz yönetim anlayışında özümsenmesi gereken faaliyetlerdir.

Konaklama ve seyahat, ulaştırma ve yiyecek-içecek işletmeleri, Covid-19 salgınının başından itibaren hayata geçirilen düzenlemelerden etkilenmişlerdir. Salgını kontrol altına alma amacıyla uçuşların durdurulup sınır kapılarının kapatılmasından maske-mesafe-temizlik uygulamalarına, şehirlerarası seyahat kısıtlamalarından Güvenli Turizm Sertifikası'na kadar bir dizi düzenleme turizm işletmelerinin rutin işleyiş̧inde değişiklik yapmalarına neden olmuştur. Rezervasyon iptalleri, kapasitelerin azaltılması, seyahatlerin kısıtlanması gibi başlıca sebeplerden ziyaretçi sayılarında azalma olmuştur. Sosyal yaşamın salgın şartlarına uyumlu hale getirilmesine yönelik düzenlemelerle vaka sayıları 2020 yılının yaz döneminde belirli bir oranda sabit kalmıştır (T.C Sağl1k Bakanlığı Covid-19 Bilgilendirme Platformu, 2020). Kontrollü gevşeme dönemi olarak adlandırabileceğimiz bu dönemde turizm işletmeleri kısıtlamalar çerçevesinde faaliyetlerini sürdürmüşlerdir ancak istatistiksel veriler düzenlemelere rağmen bir önceki yıla kıyasla ziyaretçi sayılarında çarpıcı oranda bir 
düşüş olduğunu göstermektedir. Elde edilen bulgulara bakarak söz konusu düzenlemelerin salgını kontrol altına alma, sosyal yaşamı ve iş düzenini salgın koşullarına adapte etme ve vaka-ölüm sayılarını yavaşlatma açısından etkili olduğunu ifade edebiliriz. Öte yandan dünyada ve Türkiye'de ziyaretçi sayıları ve turizm gelirlerine baktığımızda, turizm işletmelerini kapsayan düzenlemelerin büyük orandaki düşüşe engel olamadığını görmekteyiz.

Halihazırda devam eden Covid-19 salgınına karşı turizm işletmelerinde yapılan düzenlemeler turizm sektörünün yaşadığı krizi yönetmede tam anlamıyla başarılı olamamıştır. Bu başarısızlığın birçok nedeni vardır. İnsan hayatının mevzu bahis olduğu böylesi bir kriz döneminde insanların evlerine kapanıp seyahat edememeleri nedeniyle seyahat endüstrisi büyük zarar görmüştür. Uluslararası seyahatlerin sekteye uğramasının yanı sıra iç turizmde de düşüş yaşanmıştır. Söz konusu düzenlemeler ekseninde ve salgının gölgesinde geçen bir turizm sezonunun sonunda elde edilen verilere baktığımızda düzenlemeler sezonun kayıp olarak nitelendirilmesinin önüne geçememiştir. Her halükârda kayıp olacağı öngörülen turizm sezonu öncesinde, ülke çapında tam kapanma uygulanarak vaka ve vefat sayıları mümkün olan en az seviyeye düşürülebilirdi. Bu sayede yabancı misafirlerde güvenli destinasyon algısı oluşturularak ziyaretçi sayıları elde edilen verilerin üzerine çıkarılabilirdi.

Bu çalışmanın hazırlandığı Aralık ayı itibariyle salgın devam etmektedir ve aşılama faaliyetlerine başlanmıştır. Türkiye'nin de içerisinde olduğu aşı çalışmalarından olumlu haberlerin geldiği bu günlerde, ilerleyen süreçte tıpkı yaygın test gibi yaygın ve ulaşılabilir aşı uygulamalarıyla birlikte hayatın salgından önceki duruma döndürülmesi amaçlanmaktadır. Bundan sonraki süreçte aşılama çalışmalarının artması ve hızlanması öngörülmektedir. Yeterli aşı tedarikinin sağlanıp aşılamanın sorunsuz ilerlemesi, salgının kontrol altına alınmasında önemli bir adım olacaktır. Koronavirüs, üretilen aşılar sayesinde etkisini tamamen yitirse bile yaklaşık bir yıldır hayatımızın bir parçası olan ve milyonlarca insanın ölümüne, hastalanmasına ve işsiz kalmasına sebep olan salgının etkilerinin bir süre daha devam edeceği söylenebilir. Dolayısıyla salgından sonraki sürecin şimdiden planlanması, kriz sonrası yönetim anlayışıyla bu acılı sürecin ele alınması ve bu krizden çıkarılan olumlu derslere iyi çalışılarak yeni krizlerin önlenmesi veya yeni krizlere karşı daha hazır olunmasi gerekmektedir.

$\mathrm{Bu}$ çalışmada doküman analizi ve literatür taraması yöntemleri kullanılmıştır. İstatistiki veriler ikincil kaynaklardan elde edilerek derlenmiştir. Verilerin sadece Türkiye özelinde detaylandırılması çalışmanın kısıtlılığını oluşturmaktadır. Çalışmanın hazırlandığı süreçte Covid-19 salgını ve kriz yönetimi konularını bir arada ele alan çalışma sayısının az olduğu görülmüş̧ür. Covid-19 salgını bir kriz süreci olarak görülüp bu çalışma yapılmıştır. Aynı bağlamda nitel ve nicel yöntemlerle Covid-19'un turizm işletmelerine etkileri yönetici olmayan, alt, orta ve üst kademe yönetici personel ve işletme sahipleri açısından araştırılabilir.

\section{KAYNAKÇA}

AKGEMCİ, Tahir (2008), Stratejik Yönetim, Gazi Kitabevi, Ankara.

AKINCI, Zeki (2010), "Konaklama İşletmelerinde Kriz Yönetimi: Alanya Bölgesindeki Konaklama İ̧sletmelerinde Kriz Sürecinde Karş̧laşılan Sorunların Tespit ve Çözümüne Yönelik Bir Araştırma", Doktora Tezi, Süleyman Demirel Üniversitesi Sosyal Bilimler Enstitüsü, Isparta.

AKSU, Metin (2010), Kriz Yönetimi: Krizleri Fırsata Çevirmenin Yolları, Kum Saati Yayınları, İstanbul, 2.Bask1.

AKTAN, Coşkun Can (2004), “Genel Olarak Kriz Kavramı ve Özellikleri”, E-Makale, http://www.canaktan.org/yonetim/kriz-yonetim/genel-olarak.htm (Erişim Tarihi: 03.12.2020).

AMERIKA'NIN SESİ (2010), “İzlanda'da Yükselen Kül Bulutları Uluslararası Hava Trafiğini Aksatıyor”, EHaber, 16 Nisan 2010, https://www.amerikaninsesi.com/a/izlandadaki-yanardag-kul-bulutlar-havatrafigini-etkiliyor-91031274/883150.html (Erişim Tarihi: 03.12.2020).

ARSLAN, Gökhan (2013), "Liderliğin Kriz Yönetimine Etkisi Üzerine Bir Araştırma”, Yüksek Lisans Tezi, Marmara Üniversitesi Sosyal Bilimler Enstitüsü, İstanbul.

AŞIK, Mehmet (2016), “Turizm İşletmelerinde Kriz ve Kriz Yönetimi: Bodrum Bölgesindeki Beş Yıldızlı Otel İşletmelerine Yönelik Bir Araştırma", Yüksek Lisans Tezi, Necmettin Erbakan Üniversitesi Sosyal Bilimler Enstitüsü, Konya. 
AYDEMIR, Muzaffer ve DEMİRCI, Kemal M. (2005), "Son Dönemlerde Yaşanan Krizlerin İşletmeler Üzerindeki Olumlu Etkilerinin Analizi”, Cumhuriyet Üniversitesi Sosyal Bilimler Dergisi, S.29(1), ss.65-81).

BAHAR, Ozan ve ÇELIK İLAL, Nur (2020), "Coronavirüsün (Covid-19) Turizm Sektörü Üzerindeki Ekonomik Etkileri”, International Journal of Social Sciences and Education Research, S.6(1), ss.125-139.

BAYAZIT, Zeynep Özgür Çengel, DIZZDARLAR, Işın ve TEPE, Fulya (2003), "İşletmelerde Kriz Yönetimi ve Bir Vaka Çalışması", Afyon Kocatepe Üniversitesi İ̈BF 11. Ulusal Yönetim ve Organizasyon Kongresi Bildiriler Kitabı, Uyum Ajans Yayın1, Afyonkarahisar, ss.363-380.

BOIN, Arjen ve LAGADEC, Patrick (2000), "Preparing For The Future: Critical Challenges in Crisis Management", Journal of Contingencies and Crisis Management, S.8(4), ss.185-191.

BOOTH, Simon (1990), Interactive Simulation and Crisis Management Training, Contemporary Crises, S.14, ss.381-394.

BOZKULAK, Gamze (2019), “Örgüt Kültürünün Kriz Yönetimine Etkisi”, Yüksek Lisans Tezi, Sivas Cumhuriyet Üniversitesi Sosyal Bilimler Enstitüsü, Sivas.

CAN, Halil (1997), Organizasyon ve Yönetim, Siyasal Kitapevi, Ankara.

CLAIR, Judith ve DUFRENSE, Ronald L. (2007), "How Companies Can Experience Positive Transformation From A Crisis”, Organizational Dynamics, S.36(1), ss.63-77.

ÇAKMAK, Tolga Fahri (2018), “Turizm Endüstrisinde Kriz Yönetimi: Turist Rehberleri Üzerine Bir Alan Araştırması", Doktora Tezi, İstanbul Üniversitesi Sosyal Bilimler Enstitüsü, İstanbul.

ÇETİ, Buse ve ÜNLÜÖNEN, Kurban (2019), "Salgın Hastalıklar Sebebiyle Oluşan Krizlerin Turizm Sektörü Üzerindeki Etkisinin Değerlendirilmesi”, Ankara Hacı Bayram Veli Üniversitesi Turizm Fakültesi Dergisi, S.22(2), ss.109-128.

ÇİFTÇI, Gülsel (2015), “Turizm İşletmelerinde Kriz Yönetimi Uygulamalarının Örgütsel Öğrenme ve Isşletme Performansı Açısından Ampirik Olarak Analizi”, Yüksek Lisans Tezi, Namık Kemal Üniversitesi Sosyal Bilimler Enstitüsü, Tekirdağ.

ÇiTEKÇİ, Mehmet (2016), “İşletmelerin Kriz Yönetiminde Halkla İlişkilerle Etkileşim”, Yüksek Lisans Tezi, Marmara Üniversitesi Sosyal Bilimler Enstitüsü, İstanbul.

DALLARYAN, Sezar (2006), “Turizmde Kriz Yönetimi ve Kuzey Kıbrıs Türk Cumhuriyeti'nde Kriz Yönetiminin Ülke Turizminin Gelişimine Etkileri”, Yüksek Lisans Tezi, İstanbul Üniversitesi Sosyal Bilimler Enstitüsü, İstanbul.

DEMIR, Cengiz ve YILMAZ, Mustafa Kemal (2010), "Stratejik Planlama Süreci ve Örgütler Açısından Önemi”, Dokuz Eylül Üniversitesi İktisadi ve İdari Bilimler Fakültesi Dergisi, S.25(1), ss.69-88.

DEMIR, Mahmut, GÜNAYDIN, Yusuf ve ŞEN DEMIR, Şirvan (2020), "Koronavirüs (Covid-19) Salgınının Türkiye'de Turizm Üzerindeki Öncülleri, Etkileri ve Sonuçlarının Değerlendirilmesi", International Journal of Social Sciences and Education Research, S.6(1), ss.80-107.

DEMIRTAŞ, Hasan (2000), “Kriz Yönetimi”, Kuram ve Uygulamada Eğitim Yönetimi Dergisi, S.23, ss.353373.

ER, Ahmet Görkem ve ÜNAL, Serhat (2020), "Dünyada ve Türkiye'de 2019 Koronavirüs Pandemisi”, Flora Dergisi, S.25(1), ss.1-8.

GENÇ, Nurullah (2004), Yönetim Organizasyon - Çağdaş Sistemler ve Yaklaşımlar, Seçkin Yayıncılık, Ankara.

GLAESSER, Dirk (2005), Turizm Sektöründe Kriz Yönetimi, Set-Systems Tercümanlık ve Yayıncılık, İstanbul.

GÖRAL, Ramazan (2014), Turizm İşletmelerinde Stratejik Yönetim, Detay Yayıncılık, Ankara.

GUliYEV, Ali ve TOZKOPARAN, Güler (2020), Covid 19 Perspektifinde Kriz ve Kriz Yönetimi Çok Uluslu Bir İşletme Örneği, Nobel Akademik Yayıncılık, Ankara. 
GÜL, Hasan ve ÇELEBİ, Furkan (2020), "Koronavirüs (Covid-19) Pandemisinde Başlıca Gelişmiş ve Gelişmekte Olan Ülkelerde Kriz Yönetiminin Değerlendirilmesi”, MANAS Sosyal Araştırmalar Dergisi, S.9(3), ss.1703-1715.

GÜNDÜZ, Zafer (2020), "Yiyecek - İçecek İşletmelerinde Kriz Yönetimi: Restoran Yöneticilerine Yönelik Bir Uygulama (İzmir İli Örneği)", Yüksek Lisans Tezi, İzmir Kâtip Çelebi Üniversitesi Sosyal Bilimler Enstitüsü, İzmir.

INSTITUTE FOR CRISIS MANAGEMENT (2020), "Crisis", Corporate Web Page, https://crisisconsultant.com (Erişim Tarihi: 03.12.2020).

KARACA, Yasemin (2003), "Ekonomik Kriz Dönemlerinde Uygulanan Pazarlama Stratejileri”, Yüksek Lisans Tezi, Anadolu Üniversitesi Sosyal Bilimler Enstitüsü, Eskişehir.

KARAKAŞ, Yusuf Emre (2018), 'Kriz Dönemlerinde Turizm İşletmelerinde İnovasyonun Önemi: 5 Yıldızlı Otel İşletmelerinde Bir Araştırma", Yüksek Lisans Tezi, İnönü Üniversitesi Sosyal Bilimler Enstitüsü, Malatya.

KIBRITÇi̇ĞLU, Aykut (2001), “Türkiye'de Ekonomik Krizler ve Hükümetler, 1969-2001”, Yeni Türkiye Dergisi, S.(Ekonomik Kriz Özel Sayıs1), ss.1-17.

KÖROĞLU, Ahmet (2004), "Turizmde Kriz Yönetimi: Otel İşletmelerinde ve Seyahat Acentalarında Bir Uygulama", Doktora Tezi, Balıkesir Üniversitesi Sosyal Bilimler Enstitüsü, Balıkesir.

KÜÇÜKALTAN, Derman, AYDIN TÜKELTÜRK, Şule ve ÇİFTÇİ, Gülsel (2015), Otel İşletmelerinde Kriz Yönetimi, Detay Yayıncılık, Ankara.

MEYDAN, Mücahit (2005), "Kriz Yönetimi ve Muhtemel Bir Krize Karşı İşletmelerin Hazırlıklarına Yönelik Alan Araştırması: Denizli Tekstil İşletmeleri Örneğì”, Yüksek Lisans Tezi, Afyon Kocatepe Üniversitesi Sosyal Bilimler Enstitüsü, Afyonkarahisar.

MILASINOVIC, Srdan ve KESETOVIC, Zelimir (2008), 'Crisis and Crisis Management - A Contribution to A Conceptual \& Terminological Delimitation”, Megatrend Review, S.5(1), ss.167-185.

MITROFF, Ian I., SHRIVASTAVA, Paul ve UDWADIA, Firdaus E. (1987), "Effective Crisis Management", The Academy of Management Executive, S.1(3), ss.285-292.

OFLUOĞLU, Gökhan ve MISIRLI, Kamuran (2001), "İşletme ve Kriz Yönetimi”, Kamu-İş Dergisi, S.6(2), ss.16-18.

OXFORD LEARNER'S DICTIONARIES (2020), “Crisis”, Oxford Learner's Dictionaries, https://www.oxfordlearnersdictionaries.com/ (Erişim Tarihi: 31.03.2021).

ÖRNEK, Ali Şahin ve AYDIN, Şule (2008), Kriz ve Stres Yönetimi, Detay Yayıncılık, Ankara.

ÖZHASAR, Yunus ve EĞE, Zehra (2019), “Konaklama İşletmelerinde Kriz Yönetimi Uygulamaları: İstanbul Fatih Illçesi Örneğì", International Journal of Contemporary Tourism Research, S.3(1), ss.50-65.

PİRA, Aylin ve SOHODOL, Çisil (2004), Kriz Yönetimi - Halkla İlişkiler Açısından Bir Değerlendirme, İletişim Yayınları, İstanbul.

ROUX-DUFORT, Christophe ve METAIS, Emmanuel (1999), "Building Core Competencies in Crisis Management Through Organizational Learning; The Case of the French Nuclear Power Producer", Technological Forecasting And Social Change, S.1, ss.113-127.

SOYSAL, Abdullah, KARASOY, Hasan Alpay ve ALICI, Sedat (2009), "KOBI'lerde Kriz Yönetimi: Kahramanmaraş'ta Tekstil Sektöründeki KOBI'lerde Bir Uygulama”, Selçuk Üniversitesi Sosyal Bilimler Enstitüsü Dergisi, S.21, ss.431-446.

SÜRME, Metin (2020), Turizm ve Kovid-19, İKSAD Yayınevi, Ankara.

ŞAHBAZ, Ramazan Pars ve TUNA, Muharrem (1998), "Krizlerin Türk Turizmine Etkileri ve Makro Ölçekte Kriz Yönetimi Stratejileri”, 21. Yüzyılın Eşiğinde Türkiye Turizmi Sempozyumu Bildiriler Kitabı, Başkent Üniversitesi Yayınları, Ankara, ss.156.

ŞAHİN, Seda (2005), "Kriz ve Kriz Yönetimi Kapsamında Küçülme: Konakla İşletmelerinde Örnek Bir Uygulama”, Yüksek Lisans Tezi, Balıkesir Üniversitesi Sosyal Bilimler Enstitüsü, Balıkesir. 
TOKTAŞ, Yusuf - Covid-19 Sürecinde Kriz Yönetimi: Türkiye'de Turizm İşletmelerine Yönelik Düzenlemeler

T.C. KÜLTÜR VE TURIZM BAKANLIĞI (2020), Yatırım ve İşletmeler Genel Müdürlüğü Kurumsal Web Sayfası, https://yigm.ktb.gov.tr/ (Erişim Tarihi: 03.12.2020).

T.C. SAĞLIK BAKANLIĞI (2020), "Covid-19 Bilgilendirme”, Kurumsal Web Sayfası, https://covid19.saglik.gov.tr/ (Erişim Tarihi: 03.12.2020).

T.C. SAĞLIK BAKANLIĞI (2020), “Covid-19 Salgın Yönetimi ve Çalışma Rehberi”, Kurumsal Web Sayfası, https://covid19.saglik.gov.tr/TR-66393/covid-19-salgin-yonetimi-ve-calisma-rehberi.html (Erişim Tarihi: 03.12.2020).

T.C. SAĞLIK BAKANLIĞI HALK SAĞLIĞI GENEL MÜDÜRLÜĞÜ (2020), Kurumsal Web Sayfası, https://hsgm.saglik.gov.tr/tr/ (Erişim Tarihi: 03.12.2020).

TAĞRAF, Hasan ve ARSLAN, Talat (2003), "Kriz Oluşum Süreci ve Kriz Yönetiminde Proaktif Yaklaşım”, Cumhuriyet Üniversitesi İktisadi ve İdari Bilimler Dergisi, S.4(1), ss.149-160.

TOPUZ, Çetin (2009), “Kriz Yönetimi ve Turizm Sektörüne Etkileri: Belek Bölgesindeki Otel İşletmelerine Yönelik Bir Uygulama”, Yüksek Lisans Tezi, Selçuk Üniversitesi Sosyal Bilimler Enstitüsü, Konya.

TURAN, Abdulmenaf ve HAMZA ÇELIKYAY, Hicran (2020), “Türkiye'de KOVID-19 Ile Mücadele: Politikalar ve Aktörler”, Uluslararası Yönetim Akademisi Dergisi, S.(3)1, ss.1-25.

TURİZM AJANSI (2020), “Borç Yapılandırması Kabul Edildi... Turizmle İlgili Neler Var?”, E-Haber, https://www.turizmajansi.com/haber/borc-yapilandirmasi-kabul-edildi-turizmle-ilgili-neler-var-h42551 (Erişim Tarihi: 03.12.2020).

TUTAR, Hasan (2000), Kriz ve Stres Ortamında Yönetim, Hayat Yayıncılık, İstanbul.

TÜIK - TÜRKIYE İSTATISTIK KURUMU (2020), Eğitim, Kültür, Spor ve Turizm İstatistikleri, TÜİK Yayını, Ankara, https://data.tuik.gov.tr/Kategori/GetKategori?p=egitim-kultur-spor-ve-turizm-105\&dil=1 (Erişim Tarihi: 03.12.2020).

TÜRK DİL KURUMU (2020), “Kriz”, Büyük Türkçe Sözlük, TDK Yayını, Ankara, https://sozluk.gov.tr/ (Erişim Tarihi: 03.12.2020).

TÜRKIYE TURIZZM TANITIM VE GELIŞTIRME AJANSI (2020), Kurumsal Web Sayfasi, https://tga.gov.tr/ (Erişim Tarihi: 03.12.2020).

TÜZ, Melek Vergiliel (2014), Kriz Yönetimi, Uygulama İçin Temel Adımlar, Nobel Yayınları, İstanbul, 5.Bask1.

UNITED NATIONS WORLD TOURISM ORGANIZATION (2020), Corporate Web Page, https://www.unwto.org/ (Erişim Tarihi: 03.12.2020).

UZUN, Dilek (2001), "Otel İşletmelerinin Krize Hazırlıklı Olma Durumlarının Değerlendirilmesi: Beş Yıldızlı Otellerde Bir Uygulama", Yayımlanmamış Yüksek Lisans Tezi, Mersin Üniversitesi Sosyal Bilimler Enstitüsü, Mersin.

WORLD HEALTH ORGANIZATION (2020), Corporate Web Page, https://www.who.int/emergencies/diseases/novel-coronavirus-2019 (Erişim Tarihi: 03.12.2020).

YILMAZ, Özgür Devrim (2004), "Turizm İşletmelerinde Kriz Yönetimi ve Konaklama İşletmeleri Yöneticilerinin Krizlere Illişkin Yaklaşımlarına Yönelik Bir Araştırma", Yüksek Lisans Tezi, Dokuz Eylül Üniversitesi Sosyal Bilimler Enstitüsü, İzmir.

ZHU, Na, ZHANG, Dingyu, WANG, Wenling, Lİ, Xingwang, YANG, Bo, SONG, Jingdong, ZHAO, Xiang, HUANG, Baoying, SHI, Weifeng, LU, Roujian, NIU, Peihua ve ZHAN, Faxian (2020), "A Novel Coronavirus From Patients With Pneumonia in China, 2019", The New England Journal of Medicine, S.382(8), ss.727-733. 